\title{
TÜRKIYYE'DE YABANCI SERMAYELİ BANKALARIN ETKİNLİK ANALİZİ
}

\author{
Doç. Dr. İsmail MAZGíT* \\ Doç. Dr. Nilgün ACAR BALAYLAR ${ }^{* *}$
}

\begin{abstract}
ÖZ
Küreselleşme sürecinin önemli sonuçlarından birisi dış ticaret ve uluslararası sermaye hareketlerinin birçok ülkede liberalleştirilmesi olmuştur. Yabancı banka girişlerindeki artış ise bu sürecin sonuçları arasında dikkat çeken bir gelişmedir. Buna bağlı olarak da yabancı banka girişlerinin bir ülkede bankacılık sistemi üzerinde yarattı̆̆ etkilerin özellikle etkinlik boyutundan analizi çok sayıda çalışmaya konu olmuştur.

Bu çalışmada yabancı banka girişlerinin yoğun olarak yaşandiğı Türkiye'de hem yabancı bankaların hem de yerli özel ve kamu bankalarının etkinlikleri analiz edilmiştir. Malmquist Toplam Faktör Verimliliği Analizi (TFV) sonuçlarına göre yabancı bankalardaki verimlilik artışının genelde yerli bankalardan daha yüksek olduğu ve bu durumun ortaya çıkmasında teknolojik altyapının daha belirleyici olduğu tespit edilmiştir. Ayrıca yabancı bankaların TFV düzeyindeki değişmelerin alt bileşenleri incelendiğinde pür teknik etkinlik değişiminin ve ölçek etkinliği değişiminin sinırlı etkiye sahip olduğu, hem olumlu hem olumsuz değişimde teknolojik değişmenin öne çıtıtı̆ı görülmüş̧ür.
\end{abstract}

Anahtar Kelimeler: Yabancı Sermayeli Bankalar, Etkinlik Analizi, Malmquist Toplam Faktör Verimliliği.

Jel Sinıflandırması: G21, F65

\section{EFFICIENCY ANALYSIS OF THE FOREIGN BANKS IN TURKEY}

\section{ABSTRACT}

An important result of the globalization process is the liberalization of foreign trade and international capital flow in many countries. Increased entrance of foreign banks is among remarkable outcomes of this course. Due to this fact, analysis of the impact of foreign bank entrances on the domestic banking systems, especially with respect to efficiency, has been subject to numerous studies.

\footnotetext{
* Dokuz Eylül Üniversitesi, İ.İ.B.F, İktisat Bölümü, ismail.mazgit@ deu.edu.tr

** Dokuz Eylül Üniversitesi, İ.İ.B.F, İktisat Bölümü, nilgun.balaylar@deu.edu.tr
} 
In this paper, efficiency of both foreign banks and domestic private and public banks in Turkey has been analyzed, where entrance of foreign banks has been experienced intensively. According to the results of the Malmquist Total Factor Productivity (TFP) Analysis, productivity increase in case of foreign banks is found to be higher compared to that of the domestic ones, and this finding is found to be rather related to technological infrastructure. When sub-components of the changes in the TFP level of the foreign banks were further analyzed, it is identified that changes in both pure technical efficiency and in efficiency of scale had limited impact and that technological change was the leading reason for both positive and negative changes.

Key Words: Foreign Banks, Efficiency Analysis, Malmquist Total Factor Productivity.

Jel Classification: G21, F65

\section{GİRIŞ}

Küreselleşme süreciyle birlikte ülkeler arasında ekonomik ilişkilerin daha hızlı gelişmesi ve yoğunlaşması söz konusu olmuştur. Kendi kendini besleyen bir nitelik kazanan bu süreç sadece ekonomik boyutta değil sosyal, kültürel ve politik boyutlarda da yeni anlayış, uygulama ve düzenlemeleri beraberinde getirmiştir. Bu bağlamda öncelikle dış ticaret, ardından da sermaye hareketlerinin serbestleştirilmesi yönünde gerçekleşen gelişmelerin dünya genelinde üretim ve yatırımların coğrafi dağılımını yeniden şekillendirdiği görülmektedir. $\mathrm{Bu}$ gelişmeler ise başta bankacılık sektörü olmak üzere bağlantılı birçok hizmet sektöründe de değişiklikleri zorunlu kılmıştır. Genelleştirme yapılmak istendiğinde; anlayış boyutunda liberalleşme, uygulama boyutunda iç ve dış ticaret ile sermaye hareketlerinin serbestleştirilmesi, düzenleme boyutunda ise hukuki altyapının uyumlaştırılması şeklinde bir gelişme süreci yaşandığı ifade edilebilir.

$\mathrm{Bu}$ çerçevede son otuz y1ldır birçok gelişmiş ve gelişmekte olan ülkenin finansal sistemini liberalize ettiği görülmektedir. Nitekim ülkeler faiz oranları üzerindeki tavan uygulamalarını kaldırmış, rezerv gereksinimi üzerindeki baskıları azaltmış ve piyasaya girişi kolaylaştırmış, kredi tahsisindeki kararlara hükümetin müdahalesi azaltılmış ve birçok banka ve sigorta şirketi özelleştirilmiştir. Bazı ülkeler yerel sermaye piyasalarının gelişimini sağlamak için yabancı finansal aracıların sisteme girişini teşvik etmiştir. Bununla birlikte mali dengesizlikleri gidermek ve öncelikli sektörlere fon yaratmak için finansal baskıyı (financial repression) bir politika aracı olarak uygulayan çoğu gelişmekte olan ülke finansal liberalizasyona temkinli yaklaşmıştır.

Liberalizasyon yönündeki uygulamaların önemli yansıma alanlarından biri de bankacılık sektörü olmuştur. Bankacılık sektörünün liberalleşmesi denilince ilk akla gelen yabancı bankaların ulusal piyasaya girişine izin verilmesi ve buna bağlı olarak sektörde rekabetin artmasıdır. Teorik perspektifte bu gelişmenin yerli bankaların da etkinliğini artırması beklenmektedir. Kuşkusuz bu 
süreçte yaşanacak gelişmeler ülkelerin gelişmişlik düzeyleri, özgün koşulları ve sektördeki piyasa yapısına bağlı olarak şekillenecektir.

Yabancı bankaların sektörün verimlilik ve etkinlik düzeyine ne gibi bir etki yaptığını incelemeyi amaçlayan bu çalışmamızda öncelikle yabancı bankaların sektör üzerindeki olası etkileri ve buna yönelik çalışmalar incelenecektir. Ardından Türkiye'de yabancı bankalara ilişkin gelişmeler ortaya konulacak, son olarak da Veri Zarflama Analizi yöntemiyle geliştirilmiş olan Malmquist Toplam Faktör Verimliliği Endeksi yoluyla yabancı ve yerli bankaların etkinliğine ilişkin analizler yapilacaktır.

\section{YABANCI BANKA GIRIŞLERININ ULUSAL BANKACILIK SEKTÖRÜ ÜZERINE ETKÍLERI}

\subsection{Olumlu Ekiler}

Literatürde yabancı banka girişlerinin sektörde birçok olumlu etki yarattığı ifade edilmesine karşın piyasaya giren yabancı bankalar mevcut yerli bankalar ile aynı karaktere sahipse etki sadece sayısal olacaktır. Bununla beraber yabancı bankaların yerli bankaların sahip olmadığı özellikleri bünyelerinde barındırdıkları da genel kabul gören bir gerçektir.

Yabancı bankaların girişi ile artan rekabet karşısında yerli bankalar zorlanabilir ve yabancı bankaların piyasada olmadığı dönemde elde ettikleri kârlılık durumlarını devam ettiremezler. Bununla beraber bu etki uzun dönemde yerli bankaları daha kârlı ve daha etkin çalışmaya iter. Geleneksel bankacılık gelirlerindeki azalmayı telafi edebilmek için alternatif gelir kaynaklarına yönelen yerli bankalar uzun dönemde yeniden kârlılıklarını artırırlar. Diğer bir deyişle yabancı banka girişleri kısa dönemde kârlılığı olumsuz etkilerken uzun dönemde bu olumsuz etki ortadan kalkar ve kârlılık oranı tekrar yükselir. Özetle, yabancı banka girişleri ulusal bankacılık sektöründe rekabetçi bir bask1 oluşturarak ulusal bankaların daha etkin çalışmasına yol açabilir.

Yabancı banka girişleri mevcut yerli bankaların bir eksiği olan yeni finansal hizmetlerin, ileri yönetim anlayışının ve bilgi teknolojilerinin sektöre girişini sağlar. Bu etkinin daha düşük operasyonel giderlere, kârlılıkta artışa ve banka risk yönetiminde etkinliği arttırma yönünde gelişmelere yol açması beklenir. Piyasadaki rekabet nedeniyle güdülenen yerli bankalar yeni finansal ürünler ve yönetim anlayışını kendilerine örnek alabilirler. Kredi riskinin değerlendirilmesi ve fiyatlandırılmasında daha fazla deneyimin oluşması nedeniyle özel sektöre yönelik kredi tahsisi gelişir ve bu da daha yüksek bir ekonomik büyüme sağlayabilir. Yabancı yeni rakipler mevcut yerli bankalardan sağlamlık açısından daha farklı olan yerli bankaların piyasaya girmesini teşvik eder. Bu bağlamda piyasa yoğunlaşma oranı da değişeceğinden yabancı piyasa oyuncularının varlığı önemlidir (Okuda ve Rungsomboon, 5: 2004). 
Yabancı banka girişleri ev sahibi ülkeyi uluslararası muhasebe ve denetime ilişkin standartlara uyuma da zorlayacaktır. Dolayısıyla denetime ilişkin standartların gelişimi sağlanabilir.

Yabanc1 kurumlar yeni teknolojileri ithal emesi ve onların uluslararası standartlara uyumu, gelişmekte olan piyasalarda bankaları da uyuma zorlayacak ve risk yönetim teknikleri ve politikaları da gelişecektir. Ulusal bankacılık sektörü açısından uluslararası denetim ve yasal düzenlemelere uyuma zorlaması ile sektörde saydamlık artabilir (Cardenas, Graf ve O’Dogherty, 2003: 17).

Yabancı banka girişleri yerli banklardaki insan sermayesi kalitesini artırabilir. Yabanc1 bankaların yüksek deneyime sahip banka yöneticilerini ithal etmeleri ile yerli banka çalışanları bu yöneticilerin deyimlerinden yararlanabilir. Yabancı bankalar yerli çalışanların eğitimlerine yatırım yapabilir. İnsan sermayesinin kalitesinde ortaya çıkan bu artış yerli bankaların etkinliğini artırarak maliyetleri düşürebilir. Ancak bu maliyet düşüşü uzun dönemde ortaya çıkacaktır. Çünkü bankalar personel kalitesini artırabilmek için ilk etapta bir maliyetle karşılaşabilir.

Yabancı bankaların uluslar arası piyasalardan daha kolay fonlara ulaşabilmesi kredi kaynaklarına daha fazla istikrar kazandırabilir. Bu ulusal finansal piyasaların iç şoklara daha az maruz kalmasını sağlayacaktır. Diğer taraftan yabancı bankalar kriz sonrası dönemlerde yeniden sermayelendirme (recapitalazing) ve yapılanma maliyetlerini düşürebilir (Bayraktar ve Wang, 2004: 4). Yabancı bankaların yerel yönetimden daha bağımsız olmaları ve yerli firmalar ile yerli bankalar arasındaki ilişki ağının yabancı bankalar açısından daha zayıf olduğu görüşü hakimdir. Bu nedenle ekonomik koşulların bozulduğu dönemlerde yerli bankalar geri dönmeyen krediler nedeni yeni kredi vermekte zorlanırken yerel firmaların kredi ihtiyacı sermaye yapıları güçlü olan yabancı bankalar tarafından karşılanacaktır (Haas ve Lelyveld, 2002: 2). Böylece yabancı bankaların varlığı ekonomik kriz ortamında reel sektörün finansman ihtiyacını karşılayacağından krizin etkileri hafifleyebilecektir.

\subsection{Olumsuz Etkiler}

Yukarıda ifade edilen olumlu etkilere karşın yabancı banka girişleri ulusal ekonomi üzerinde olumsuz etkiler de yaratabilmektedir.

Yabancı banka girişleri sonucunda küçük ve orta ölçekli teşebbüslerin krediye ulaşma imkanı azalabilir. Gelişmekte olan ülkelerde istihdamın yüzde ellisinden daha fazlasının küçük ve orta ölçekli işletmelerde olduğu düşünülürse bu firmaların krediye ulaşma yeteneklerinin düşmesi tüm ekonomik performansı olumsuz yönde etkileyebilir (Clarke, Cull ve Martinez Peria, 3: 2002).

Finansal serbestleşmenin artırdığı rekabet bankaların kârlarını azaltacaktır. Kârlardaki azalma bankaların imtiyaz değerinde (franchise value) düşüşü beraberinde getirir. Bu ise bankaları getirisi daha yüksek riskli kredi alanlarına yönlendirir. Böylece sektörde ahlaki tehlike (moral hazard) sorunu 
$\operatorname{artar}$ (Hellman, Murdock ve Stiglitz, 2000: 2-28). Aynı zamanda daha avantajlı ürün ve hizmetle yabancı bankalar iç piyasalarda daha yüksek kârlılık payına sahip olabilir. Ulusal bankaların kârlılık payını artırma yarışına girmesi sektörü daha riskli hale getirebilir.

Ekonomik istikrar üzerine yabancı bankaların olumlu etkisinden söz edilmekle beraber ülkede ortaya çıkan problemler nedeniyle ev sahibi ülkeleri terk etmesi finansal istikrarsızlığı artırabilir. Ayrıca, yabancı bankalar farklı önceliklere ve problemlere odaklandıklarından kredilendirme modellerinde iç öncelikleri dikkate almama eğilimindedirler (Bayraktar ve Wang, 2004: 4).

Yabancı banka girişlerinin ulusal bankalar üzerinde etkileri ekonomin gelişmişlik düzeyine bağlıdır. En azından kısa dönemde ekonomik gelişmişlik düzeyinin düşük olduğu ülkelerde yabancı banka girişleri maliyetleri ve beklide yerli bankaların marjlarını artıracaktır. Daha yüksek gelişmişlik düzeyine sahip ülkelerde yabancı banka girişlerinin etkileri ya hiç olmayacaktır ya da maliyetler ve marjlar düşecektir. Yerli bankaların kârlarına yönelik etki ise gelişmişlik düzeyi daha düşük olan ülkelerde belirsizdir. Çünkü hem maliyetler hem de marjlar artmaktadır. Daha yüksek gelişmişlik düzeyine sahip olan ülkelerde ise yabancı banka girişleri rekabeti artıracağından kârlar düşebilecektir. Özetle yabancı banka girişlerinin etkileri daha az gelişmiş finansal sisteme sahip ülkelerde daha fazladır (Lensink ve Hermes, 2004: 5). Yabancı banka girişlerinin etkileri açısından göz önünde bulundurulması gereken diğer bir faktör piyasaya giren yabancı banka sayısı ve söz konusu bankaların piyasa paylarıdır. Yabancı bankaların ulusal bankacılık sektörü üzerinde olumlu etkilere sahip olabilmesi için çok sayıda ancak düşük piyasa payına sahip olmaları gerekir. Yabancı bankaların piyasa payları yükseldikçe ulusal bankalar ile aralarındaki rekabet yerini monopol gücünü kullanmasına bırakır. Bu durumda süreç ekonomiye zarar verecektir.

\section{BAZI AMPÍRÍK ÇALIŞMALAR VE SONUÇLARI}

Yabancı banka girişlerinin ulusal bankacılık sektörü üzerine etkilerine yönelik bir çok ampirik çalışma yapılmıştır. Yapılan çalışmalar konuya ilişkin görüşleri destekler niteliktedir ve yabancı banka girişlerinin sektörde rekabeti artırdığına ilişkin bulgular oldukça yaygındır.

Okuda ve Rungsonboom tarafindan Tayland ulusal bankacılık sistemine yabancı banka girişlerinin etkileri, 17 ticari bankaya ilişkin 1990-2002 yıllarına ait veriler ile panel data kullanılarak araştırılmıştır. Bulguları yabancı banka girişleri ile ulusal bankaların genel gider harcamalarının ve faiz marjlarının arttığı ve kârlarda bir düşüş ortaya çıktığı yönündedir. Yabancı banka girişlerinin kısa dönemde ulusal bankacılık üzerinde olası negatif etkilerine karşın uzun dönemde bankaların tüm alanlarda iyileşme göstereceği beklenmektedir. Çalışmada aynı zamanda yabancı banka girişleri ile piyasa yoğunlaşmasının değişmesiyle piyasa yapısının değiştiği de ortaya konulmuştur. Düzenlemelerin diğer bir etkisi banka davranışları üzerine olduğu tespit edilmiştir (Okuda ve Rungsomboon, 2004: 15-16). 
Claessens- Demirgüç- Huizinga tarafından 80 ülkeyi kapsayan 1988-1995 yıllarına ait verilerle yapılan çalışmada yerli ve yabancı bankalar net faiz marjı, kârlılık, genel gider maliyetleri ve vergi ödemeleri açısından bir karşılaştırma yapılmıştır. Gelişmiş ülkelerdeki gerçeğin tersine yabancı bankalar gelişmekte olan ülkelerde yerli bankalara göre daha yüksek net faiz marjı, kârlılık ve vergi ödeme eğilimindedirler. Literatürde yabancı banka girişlerinin sektörde rekabete yol açarak yerli bankaların daha etkin çalışacağı yönündeki genel görüşe vurgu yapılarak, yabancı banka payındaki artışın yerli bankaların genel giderlerinde ve kârlılığında bir düşüş ortaya çıkaracağı ampirik olarak kanıtlanmıştır. Bu sonuçların banka müşterileri için pozitif refah etkisi yaratarak yabancı banka girişlerinin ulusal bankacılık sektörünün işlevselliğini artıracağı yönündeki görüşü desteklemekte olduğu ileri sürülmüştür (Claessens, Demirgüç ve Huizinga,1998: 17).

Pasadilla ve Milo çalışmasında Filipinlerde 1990'larda bankacılık sektöründe rekabeti artırmaya yönelik reform politikalarının etkilerini analiz etmiştir. Özelikle de ulusal bankalar ve yabancı banka girişleri üzerindeki kısıtlamaların kaldırılmasının yanı sıra bankacılık piyasa yapısını, performansını ve rekabeti etkileyen konsolidasyon eğiliminin sektörü nasıl etkilediği ortaya konulmaya çalışılmıştır. Çalışmada bankalar büyüklüklerine göre alt gruplara ayrılmıştır. Yapılan analizde büyük ve uluslar arası bankaların rekabeti düşürdüğü ve bu bankaların monopolcü rekabet davranışına sahip olurken orta ve küçük bankaların ise daha rekabetçi bir yapı sergilediği sonuçlarına ulaşılmıştır. Orta ve küçük bankaların birleşmesiyle ortaya çıkan bankalar ayrı bir grup olarak incelenmiş ve bu bankaların da daha rekabetçi bir yapı sergilediği ortaya çıkmıştır. Çalışmanın ana vurgusu bankacılıkta rekabet artışının büyük bankalardan ziyade küçük banklar tarafından gerçekleştirildiğidir (Pasadilla ve Milo, 2005: 21).

Clarke, Cull, Peria tarafindan 36 gelişmekte olan ve geçiş sürecinde olan ekonomilerde 3000 girişimciye yönelik yapılan anket çalışması ile yabancı banka girişlerinin girişimcilerin krediye ulaşma yeteneği üzerindeki etkisi araştırılmıştır. Çalışmanın sonucunda tüm ölçekteki firmaların yabacı banka girişleri ile krediye ulaşma yeteneğinin arttığı sonucuna ulaşılmıştır. Yabancı banka girişleri ile büyük ölçekli firmaların küçük ölçeklilere göre daha fazla yarar sağlayacağı görüşüne karşın küçük ölçekli firmaların dahi yarar sağladığı ve yabancı banka girişleri ile herhangi bir zarara uğramadığı yönünde güçlü kanıtlar elde edilmiştir (Clarke, Cull ve Peria, 2002: 21).

1989-1996 dönemine ilişkin aylık verilerin kullanıldı̆̆ İsrail bankacılık sistemine ilişkin Ribon-Yosha tarafından yapılan çalışmada kredi piyasası ve mevduat piyasasına ilişkin iki ayrı analiz yapılmış, her iki piyasa içinde tam rekabetin geçerli olmadığı ve kredi piyasasındaki rekabetin mevduat piyasasındaki rekabetten daha düşük olduğu ortaya çıkmıştır. İki piyasa birleştirildiğinde rekabete ki artış istatistikî olarak daha büyük ve önemli olmuştur. Kredi talep şedülünde Euro faiz oranı tahmin katsayısı söz konusu dönemin ikinci yarısında daha da artmıştır. Bu bulguların uluslararası finansal serbestleşmenin bankacılık sektöründe rekabeti artırdığını gösterdiği ileri 
sürülmüştür. Yazarlar, ayrıca bankacılık sektöründe artan rekabetten daha fazla kimlerin yarar sağladığının da önemli bir konu olduğu üzerinde durmuşlardır. Artan rekabetten büyük olasılıkla daha çok büyük firmaların, ihracat ağırlıklı firmaların ve denizaşırı finansal piyasalara ulaşabilen varlıklı bireylerin küçük firmalar ve düşük varlıklı hane halklarına göre daha fazla fayda sağladıkları ileri sürülmüştür (Ribon ve Yosha, 2001 :24).

Claessens ve Lee çalışmasında düşük gelirli ülkelerde son dönemlerde artan yabancı banka girişlerine dikkat çekmiştir. Bu gelişmenin ulusal bankacılık sistemi için finansal aracılık maliyetlerinde azalma ve sistemin daha etkin çalışmasına yol açığı görüşü ortaya konulmuştur. Özelikle ev sahibi ülke için ana ülkeden denetim ve gözetime ilişkin yapılan uyumlaştırmanın bankacılık sisteminin daha güçlü olmasına yol açtığı ileri sürülmüştür. Yazarlar özellikle uzun dönemli tarihsel bağlara sahip olan bazı ülkelerde yabancı banka girişlerinin ulusal bankacılık sistemi üzerindeki rolüne de değinmiştir (Claessens ve Lee, 2002: 22).

Denizer ve diğerleri yabancı banka girişlerinin 1980-1997 yılları arasında Türkiye'de finansal sektör üzerine etkilerini analiz etmiştir. Çalışmada yabancı banka girişlerinin ulusal bankacılık sektörü üzerinde çeşitli yollarla yarar sağladığı vurgulanmıştır. Özellikle finansal ve operasyonel planlamada, kredi analizi ve pazarlamasında ve insan sermayesinde yabancı bankaların ulusal sisteme önemli yararlar sağladığına değinilmiştir. Çalışmada performans ölçütü olarak genel giderler, net faiz marjı ve aktif getirisi üzerinde durulmuştur. Söz konusu dönemde ulusal bankaların yabancı girişiyle genel giderlerin, net faiz marjının ve aktif getirisinin düştüğü sonucuna varılmıştır (Denizer, 1999: 19).

\section{TÜRKIYE'DE YABANCI BANKA GİRIŞLERI}

Ülkemizde, planlı dönemde hızlı bir ekonomik kalkınma sağlanmış ancak sanayileşmenin finansmanında enflasyona yol açan yöntemler kullanılmıştır. Yüksek gümrük vergileriyle korunan ulusal sanayi daha çok iç tüketime yönelik ve katma değeri düşük bir üretim yolunu benimsemiştir. Aynı zamanda uygulanan sabit kur sistemi döviz kurlarının gerçekçi değerinin altında kalmasına ve ithal girdi bağımlılığının artmasına yol açmıştır. Bu süreç özellikle 1970’li yılların ikinci yarısında önemli bir döviz darboğazının yaşanmasına neden olmuştur. Buna bağlı olarak, ithal girdi sağlanmasında karşılaşılan sorunlar nedeniyle fabrikaların eksik kapasite ile çalışmaya başlaması, 1980 yılında dışa açık sanayileşme stratejisinin benimsenmesine yol açmıştır. Bu hedefler doğrultusunda, ekonominin gereksinimlerinin karşılanabilmesi için, finansal piyasalarda liberalizasyon ve derinleşmenin sağlanmasına yönelik olarak, 1980 yılından itibaren çeşitli yasal ve kurumsal düzenlemeler yapılmıştır (TBB,1998: 17).

Türkiye'de 1929 sonrası faaliyete geçen ilk yabancı banka 1977 yılında kurulan Arap -Türk Bankası olmuştur. Bankanın kuruluş amacı, uluslar arası bankacılık yapmak ve uluslar arası finans 
pazarlarından kaynak sağlamaktı. 1980 Yılında Türkiye'de faaliyette bulunan yabancı banka sayısı 4 olup bu bankaların mevduat - kredi piyasasındaki payı da \%2 - \%3 aralığındadır (Akgüç, 2007: 12).

1980'e kadar yabancı rekabetine karşı aşırı korumacı bir tutum sergilenmesi bankacılık sektöründe devletin payının yüzde ellinin üzerine çıkmasına yol açmıştır. 1980 öncesi dönemde yabancı girişlerine yönelik kısıtlamalar ticari bankaların hemen hemen rekabetin olmadığ ve dolayısıyla yüksek kârların söz konusu olduğu oligopolistik bir yapıda faaliyet sürmelerine yol açmıştır.

Dışa yönelik büyüme stratejisine geçilmesiyle yapısal uyum programının bir parçası olarak Türkiye ekonomisi genelde ve özellikle de finansal sistemde önemli liberalizasyon uygulamalarını yürürlüğe koymuştur. Bu reformlar tamamlayıcı olarak bankacılık sektörüne yönelik iki anahtar öğeyi içeriyordu: Faiz oranları üzerindeki kontrolleri kaldırmak, etkinlik ve rekabet artışını sağlamak için bankacılık sistemine yabancı girişleri üzerindeki kısıtlamaları hafifletmek (Denizer ve Dinç, 2000: 67). 1980’li y1llarda devam eden mali reformlar Türk bankacıllk sektöründe köklü değişimler yaşanmasına yol açmışır. Doğrudan kredi politikalarının kaldırılması, kredi ve mevduat faizleri üzerindeki kontrollerin kaldırılması, döviz kuru sisteminin liberalize edilmesi, piyasaya giriş engellerinde gevşeme, yeni finansal piyasalar ve kurumların kurulması, uluslar arası bankacılık düzenleme standartlarının benimsenmesi sektörde rekabeti beslerken aynı zamanda Türkiye ekonomisinin dünya ekonominse entegrasyonunu da hızlandırmıştır (Işık ve Uysal, 2006: 366). Dünya'da ve Türkiye reel ve finansal kesime yönelik serbestleşme eğiliminin hız kazanması 1980 sonrası yabancı banka girişleri için elverişli bir ortam yaratmış ve 1980 Yılında sayısı 4'e değin gerilemiş olan yabancı banka sayısı 1991 yılında 21'e yükselmiştir.

Yüksek kamu açıklarının yol açtığı artan kamu kesimi borçlanma gereği yüksek enflasyon ve reel faizler nedeniyle 1990'lı yıllar ise artan oranda istikrarsızlıkların yaşandığ Kamunun aşırı borçlanma gereği bankaların fonlarını daha çok kısa vadeli devlet borçlanma kâğıtlarına yöneltmiş ve böylece özel sektörün krediye erişimi güçleşmiştir. Yatırım tasarruf dengesinin bozulduğu söz konusu dönemde sektöre yeni yerli oyuncular girmiş ve kısa vadeli toplanan fonlar bankanın bağlı olduğu grup tarafından yapılan uzun vadeli ve/veya yüksek riskli projelere aktarılmıştır. 1999, 2000 ve 2001 yıllarında yaşanan finansal bunalım dönemlerini atlatamayan bu bankalar sistem dışına çıkmışlardır. Finansal istikrarsızlık dönemi olarak adlandırabileceğimiz 19902001 yılları arasında sistemdeki yerli bankalar gibi yabancı banka sayısında da azalma olmuştur (BDDK, 2005: 35-36).

Tablo1. Türkiye Bankacılık Sektöründe Mülkiyete Göre Banka Sayıları

\begin{tabular}{|c|c|c|c|c|}
\hline Yıllar & Ulusal & Yabancı & Toplam & Yabancı Banka Payı (\%) \\
\hline 1980 & 39 & 4 & 43 & 9,3 \\
\hline 1985 & 35 & 15 & 50 & 30,0 \\
\hline 1990 & 43 & 23 & 66 & 34,8 \\
\hline 1995 & 50 & 18 & 68 & 26,5 \\
\hline
\end{tabular}




\begin{tabular}{|l|c|c|c|c|}
\hline Yıllar & Ulusal & Yabanc & Toplam & Yabanci Banka Payı (\%) \\
\hline 2000 & 61 & 18 & 79 & 22,8 \\
\hline 2001 & 43 & 18 & 61 & 29,5 \\
\hline 2002 & 36 & 18 & 54 & 33,3 \\
\hline 2003 & 33 & 17 & 50 & 34,0 \\
\hline 2004 & 33 & 15 & 48 & 31,3 \\
\hline 2005 & 32 & 15 & 47 & 31,9 \\
\hline 2006 & 27 & 19 & 46 & 41,3 \\
\hline 2007 & 24 & 22 & 46 & 47,8 \\
\hline 2008 & 24 & 21 & 45 & 46,7 \\
\hline 2009 & 24 & 21 & 45 & 46,7 \\
\hline 2010 & 24 & 21 & 45 & 46,7 \\
\hline 2011 & 24 & 20 & 44 & 45,5 \\
\hline 2012 & 25 & 20 & 45 & 44,4 \\
\hline
\end{tabular}

Kaynak: TBB, Bankalarımız, çeşitli sayılar, www.tbb.org.tr

2001 krizi öncesinde ülkemizde yabancı banka girişleri yeni banka kurulması veya şube açılması şeklinde gerçekleşirken, kriz sonrasında yabancı sermaye ulusal bankaların paylarını satın alarak, söz konusu bankalarda sermaye çoğunluğuna veya nitelikli paya sahip olması şeklinde gerçekleşmiştir. Yaşanan krizle beraber döviz kurlarının önemli oranda artmasın yanı sıra bankaların finansal açıdan zayıflamaları ile değerlerinin olumsuz etkilenmesi, özelleştirme politikasına hız verilmesi, Türkiye ekonomisinin dışa açıklık oranının artması, Basel II’nin etkisine ilişkin beklentiler, finans sektöründe birleşme ve satın alma eğilimleri, yabancı sermayenin bankacılık sektörüne geliş ve örgütlenme biçimini etkilemiştir (Akgüç, 2007:12-13).

Yukarıdaki Tablo'da 1980 sonrası Türkiye'de bankacılık sektöründe faaliyet gösteren bankaların sermaye yapılarına göre sayıları verilmiştir. 1980 sonrası dönemde serbestleşme politikaları sonucunda yabancı banka payının banka sayısı açısından önemli düzeyde arttığı görülmektedir. 90'lı Yııllarda yabancı banka sayısı azalırken ulusal banka sayısındaki artış yabancı banka payının düşmesine neden olmuştur. 2000 ve 2001 yılında yaşanan kriz sürecinde bir çok bankanın tasarruf mevduatı sigorta fonuna devredilmesi ve kriz sonrasında bankacılık sektörü yeniden yapılandırma programı çerçevesinde banka birleşmelerinin gerçekleşmesi ile ulusal banka sayısındaki düşüş yabancı banka payının sektörde artmasına yol açmıştır. Özellikle 2006 yılında yabancı banka girişlerindeki artışla beraber yabancı banka payının artışı dikkat çekicidir. 2012 yılı itibariyle sektörde toplam banka sayıs1 45 olup bunların 20'si (16's1 mevduat bankası 4'ü kalkınma ve yatırım bankası) yabancı sermayelidir. Banka sayısı açısından yabancı sermayeli bankaların sektördeki payı ise yüzde 44,4'e ulaşmıştır. 
Tablo 2. Yabancı Sermayeli Mevduat Bankalarının Sektör Payları

\begin{tabular}{|c|c|c|c|c|}
\hline & Yabancı Banka Sektör Payı (Aktif) (\%) & Mevduat & Krediler & Serbest Özsermaye \\
\hline 1990 & 3 & 2 & 3 & - \\
\hline 1999 & 5 & 3 & 3 & -70 \\
\hline 2000 & 5 & 3 & 3 & -28 \\
\hline 2001 & 3 & 2 & 3 & - \\
\hline 2002 & 3 & 2 & 4 & 19 \\
\hline 2003 & 3 & 2 & 4 & 8 \\
\hline 2004 & 3 & 3 & 5 & 7 \\
\hline 2005 & 5 & 3 & 7 & 8 \\
\hline 2006 & 12 & 10 & 15 & 14 \\
\hline 2007 & 15 & 14 & 19 & 16 \\
\hline 2008 & 15 & 13 & 18 & 17 \\
\hline 2009 & 13 & 13 & 18 & 15 \\
\hline 2010 & 13 & 12 & 15 & 15 \\
\hline 2011 & 14 & 13 & 14 & 14 \\
\hline 2012 & 14 & 14 & 15 & 14 \\
\hline
\end{tabular}

Kaynak: Bankalarımız Kitabı, Çeşitli Sayılar, www.tbb.org.tr

Bankacılık sektöründe yabancı bankaların payı banka sayılarının yanı sıra toplam aktifler, mevduat ve krediler içindeki payı açısından da değerlendirilmelidir. Yabancı banka payının sayı açısından 2005 yılı sonrasındaki gösterdiği artış trendi toplam aktif, mevduat ve kredilerdeki payda da görülmektedir (Tablo 2). 2012 yılı itibariyle yabancı bankaların sektör aktifinin ve toplam mevduatların yüzde 14'üne sahip iken, toplam kredileri içindeki payı ise yüzde 15 'tir. Halka açık paylar da dikkate alındığında Mayıs 2012 itibariyle yabancıların sektörün aktif büyüklüğünden aldığ 1 pay yüzde 41'dir. Serbest özsermaye açısından bakıldığında yabancıların payı yüzde 13,76'dır.

\section{MALMQUIST TOPLAM FAKTÖR VERIMLILLIĞİ ENDEKSLERIYLE YABANCI SERMAYELİ BANKALARIN VERIMLILİK ANALİİ}

\subsection{Uygulamanın Teorik Altyapısı: Malmquist Toplam Faktör Verimliliği}

Etkinlik ve verimlilik ölçümlerinde genellikle üç yöntem kullanılmaktadır: Oran analizi, parametrik yöntemler, parametrik olmayan yöntemler. Her bir yöntemin artıları ve eksileri bulunmaktadır. Oran analiziyle yapılan çalışmalarda, bir girdi ve bir çıktının söz konusu olduğu üretim birimleri açısından tatmin edici sonuçlara ulaşılabilmekte; buna karşın birden fazla girdi ve çıktının söz konusu olduğu üretim birimlerinin verimlilik analizlerinde karşılaştırma yapmak güçleşmektedir. Böyle bir üretim birimi için tek bir oran kullanılarak verimlilik ölçümü yapılması durumunda ölçümlerin yetersiz kalacağı, birden fazla oran kullanılması gerektiği durumlarda hangi orana ne düzeyde ağırlık verileceğinin belirlenmesi en önemli sorundur. Parametrik yöntemlerde ise etkinlik ve verimlilik analizi yapılacak farklı işletmelerin ortalaması dikkate alınmakta ve ayrıca etkinlik analiz kapsamına alınan karar birimlerinin ortalamasının dikkate alınması gerekmektedir. Bunların dışında bir diğer önemli sorun, analiz edilecek karar birimlerine yönelik olarak girdi ve çıktılar arasındaki fonksiyonel ilişkinin biçimine ilişkin bir takım varsayımlara gereksinim duyulmaktadır. 
Parametrik olmayan analiz yöntemlerinde ise girdiler ve çıktılar arasında var olan fonksiyonel ilişkinin biçimine yönelik bir varsayım gerekmemesi; birden fazla girdi ve birden fazla çıktının kullanılarak analiz yapılmasının olanaklı olması en önemli avantajlarını oluşturmaktadır. Bu analiz yöntemlerinden en popüler olanı Veri Zarflama Analizi (VZA) olarak bilinen analizdir.

VZA tekniği doğrusal programlama tabanlı parametrik olmayan bir tekniktir. İlgili üretim teknolojisi için sonlu sayıda parametresi olan ve fonksiyonel formu belirlenmiş bulunan bir fonksiyon sınıfına ait olma varsayımı yapılmamıştır (Tarım, 2001: 45). VZA ortaya atıldığı 1978 yılından beri gittikçe genişleyen bir uygulama alanına sahip olmuştur (Tarım, 2001: 50). Özellikle başlangıç yıllarında kâr amacı gütmeyen kamusal niteliği ağırlıklı olan organizasyonlarda etkinlik ölçümlerinde sıklıkla kullanılmıştır.

Birden çok ve farklı ölçeklerle ölçülmüş girdi ve çıktıların karşılaştırma yapmayı zorlaştırdığı durumlarda, karar verme birimlerinin göreceli performanslarını ölçmek için VZA uygun bir yöntemdir. Literatürdeki adıyla Data Envelopment Analysis, spesifik olarak karar verme birimlerinin (Decision Making Units) göreceli verimliliğini tahmin etmek için tasarlanmış olan parametrik olmayan bir yöntemdir. VZA'nde Karar Verme Birimi (KVB) ifadesi, birtakım girdileri birtakım çıktılara dönüştürmekten sorumlu işletme veya ekonomik kuruluşlar olarak tanımlanır. $\mathrm{Bu}$ tanıma şirketler, organizasyonlar, şirket içindeki bölümler, şehirler, hükümet programları veya ülkeler dâhil edilebilmektedir (Çipil, 2011: 33).

VZA, belli kısıtlar altında girdilerle çıktılar arasındaki ilişkiyi inceler ve yatay kesit olarak düzenlenmiş veri setinde yer alan her bir karar verme biriminin etkinlik düzeylerini belirler. $\mathrm{Bu}$ gözlemler içinde yer alan en etkin KVB ile diğer her bir KVB arasındaki farklılıkları dikkate alarak, etkin olmayan KVB için etkinsizliklerin giderilebilmesine yönelik önerilerde bulunmayı da olanaklı k1lar.

Ancak VZA statik bir analiz yöntemidir. Bir başka ifadeyle, VZA ile belli bir durum tespiti yapılarak, o veri setinin geçerli olduğu an için etkinlik düzeylerini hesaplar. Ne var ki, belli bir zaman diliminde etkin olan $\mathrm{KVB}$, bir süre sonra bu etkinliğini yitirmiş olabilir. Bu nedenle VZA yönteminden hareketle zaman içinde etkinlik düzeylerinin nasıl geliştiğini belirleyecek bir araştırma yöntemine gerek duyulmuştur. $\mathrm{Bu}$ gereksinimi karşılayan yöntem Malmquist Toplam Faktör Verimliliği (TFV) endeksidir.

Malmquist TFV endeksi, Veri Zarflama Analizi (VZA) yöntemine dayalı bir tekniktir. VZA etkin karar birimlerinin oluşturduğu etkin üretim sınırına göre her bir karar verme biriminin etkinlik ölçüsünü hesaplamaktadır. Malmquist TFV endeksi ise bir karar biriminin iki zaman dilimi arasında verimliliğin değişimini ölçmektedir (Öncü ve Aktaş, 2007: 252). Dolayısıyla Malmquist endeksi dinamik bir göstergedir. 
Malmquist toplam faktör verimliliği (TFV) endeksi iki gözlemin toplam faktör verimliliğindeki değişmeyi ortak bir teknolojiye olan uzaklıkların oranı olarak ölçer. Bu ölçüm için uzaklık fonksiyonu kullanılmaktadır. Caves ve diğerleri (1982) tarafindan geliştirilen bu endekse, uzaklık fonksiyonları yardımıyla endeks kurma fikrini ilk ortaya atan Sten Malmquist'in ardından, Malmquist ismi verilmiştir (Cingi ve Tarım, 2000: 10).

Karar birimlerine ilişkin panel verinin derlenebilmesi halinde toplam faktör verimliliğindeki değişme incelenebilmektedir. Benzer amaca yönelik olarak kullanılan Tornqvist/Fisher endekslerinden farklı olarak, Malmquist TFV endeksinin oluşturulabilmesi için ilgili karar birimlerinin kâr maksimizasyonu veya maliyet minimizasyonu hedefledikleri varsayımına gerek bulunmamaktadır. $\mathrm{Bu}$ bağlamda, Tornqvist/Fisher metodu için gerekli olan fiyat verisinin derlenmesi Malmquist metodu için zorunlu değildir. Böylece, özellikle kamu sektörü veya kâr amacı gütmeyen organizasyonların performansının ölçümünde zaman boyutunu dikkate alabilecek güçlü bir yöntem olarak değerlendirilmektedir (Tarım, 2001: 151-152).

Malmquist endeksi baz yıla göre etkinlik değişimini zincirleme endeks bağlamında ele alan bir yaklaşımdır. Baz yıl ve izleyen yıllar için üretim sınırını ve her bir firma için bu sınırlara göre etkinlik hareketini tahmin eder. Malmquist endeks baz yıl değerini 1 kabul ederek etkinlik değişimini ölçen bir yaklaşımdır. Eğer endeks değeri 1'den büyükse, baz yıla göre etkinlikte bir gelişme; eğer endeks değeri 1'den küçükse, baz yıla göre etkinlikte bir gerileme söz konusudur. Bu etkinlik değişimleri, teknik etkinlikteki (catching up) değişim ve teknolojik değişim (technological change) olarak iki bileşenden oluşur. Firmaların teknik etkinliklerindeki değişim de, pür teknik etkinlikteki (pure technical efficiency) değişim ve ölçek etkinliği (scale efficiency) değişiminden oluşur. Bu bileşenler arasındaki ilişkiler ise şöyle ifade edilebilir (Sturm ve Williams, 2002: 8):

\begin{tabular}{|c|c|c|c|c|}
\hline $\begin{array}{l}\text { Toplam Faktör Verimliliăindeki } \\
\text { Değişme }\end{array}$ & $=$ & Teknik Etkinlikteki Değişme & $\mathrm{x}$ & Teknolojik Değişme (1) \\
\hline Teknik Etkinlikteki Değişme & & $\begin{array}{l}\text { Pür Teknik Etkinlikteki } \\
\text { Deŏisme }\end{array}$ & $\mathrm{x}$ & $\begin{array}{c}\text { Ölçek Etkinliği } \\
\text { Değisisimi }\end{array}$ \\
\hline
\end{tabular}

Teknik etkinlikteki değişme üretim sınırını yakalamayı, teknolojik değişme de üretim sınır eğrisinin yer değiştirmesini ifade etmektedir. Pür etkinlik değişimi ölçeğe göre değişen teknoloji koşulu altında teknik etkinlikteki değişimi ölçmektedir. Ölçek etkinliği değişimi ise ölçeğin değişimi sonucunda verimlilikteki değişmeyi kapsamaktadır. Bu ayrıştırma Caves, Christensen ve Diewert (1982) tarafından geliştirilmiştir (Büyükkılıç ve Yavuz, 2005'den aktaran Aras ve Gencer, 2011: 145).

Malmquist toplam faktör verimliliği endeksi iki gözlemin toplam faktör verimliliğindeki değişmeyi ortak bir teknolojiye olan uzaklıkların oranı olarak ölçer. Bu ölçüm için uzaklık fonksiyonu kullanılmaktadır. Girdi uzaklık fonksiyonu, çıktı vektörü verildiğinde, oransal olarak en çok büzülen (contraction) girdi vektörüne bağlı olarak üretim teknolojisini tanımlar. Benzer olarak, çıktı uzaklık 
fonksiyonu, girdi vektörü verildiğinde, oransal olarak en çok genişleyen (expansion) girdi vektörüne bağlı olarak üretim teknolojisini tanımlar (Tarım, 2001: 152 - 153).

Uzaklık fonksiyonu çok-girdili çok-çıktılı üretim teknolojilerini, maliyet minimizasyonu veya kâr maksimizasyonu gibi hedefleri belirtmeden, tanımlamada kullanılmaktadır ${ }^{1}$. Çıktıya göre uzaklık fonksiyonu $d(x, y)=\min \{\delta:(y / \delta) \in S\}$ olarak tanımlanır. Uzaklık fonksiyonu $d(x, y)$ 'nin alacağı değerler, $y$ vektörü $S$ sınırı (üretim sınırı) üzerinde ise 1; $y$ vektörü $S$ içindeki teknik etkin olmayan bir noktayı tanımlıyorsa $>1$; ve $y$ vektörü $S$ dışındaki mümkün olmayan bir noktayı tanımlıyorsa $<1$ 'dir.

Malmquist TFV değişim endeksi, esas alınan $s$ dönemi ve izleyen $t$ dönemi arasındaki çıktıya göre uzaklık fonksiyonu çerçevesinde,

$$
m\left(Y_{s}, X_{s}, Y_{t}, X_{t}\right)=\left[\frac{d^{s}\left(Y_{t}, X_{t}\right)}{d^{s}\left(Y_{s}, X_{s}\right)} \times \frac{d^{t}\left(Y_{t}, X_{t}\right)}{d^{t}\left(Y_{s}, X_{s}\right)}\right]^{1 / 2}
$$

olarak hesaplanır. Bu gösterimde $d^{s}\left(X_{t}, Y_{t}\right), t$ dönemi gözleminin $s$ dönemi teknolojisinden olan uzaklı̆̆ını ifade eder. Yukarıdaki eşitlik aşağıdaki gibi yazılabilir:

$$
m\left(Y_{s}, X_{s}, Y_{t}, X_{t}\right)=\left(\frac{d^{t}\left(Y_{t}, X_{t}\right)}{d^{s}\left(Y_{s}, X_{s}\right)}\right) \times\left[\left(\frac{d^{s}\left(Y_{t}, X_{t}\right)}{d^{t}\left(Y_{t}, X_{t}\right)} \times \frac{d^{s}\left(Y_{s}, X_{s}\right)}{d^{t}\left(Y_{s}, X_{s}\right)}\right)\right]^{1 / 2}
$$

Eşitliğin sağ tarafındaki ilk terim dönem $s$ ve dönem $t$ arasındaki toplam teknik etkinlik değişmesinin ölçüsüdür. Parantez içindeki ifade ise teknik değişmeyi ifade eder.

Bir ampirik çalışmada ardışık iki dönem için hesaplama yapabilmek için dört uzaklık fonksiyonunun da bulunması gerekmektedir. Bu hesaplama ise matematiksel programlamayla veya ekonometrik tekniklerle gerçekleştirilebilir. TFV endeksi için kullanılan uzaklık fonksiyonlarının hesaplanmasında günümüzde en çok başvurulan yaklaşım olan, Fare ve diğerleri (1994)'ün geliştirdiği, matematiksel programlama modelleri matris notasyonuyla aşağıda verilmiştir.

$$
\begin{array}{ll}
{\left[d^{t}\left(y_{t}, x_{t}\right)\right]^{-1}=\max _{\phi, \lambda} \phi} & {\left[d^{s}\left(y_{s}, x_{s}\right)\right]^{-1}=\max _{\phi, \lambda} \phi} \\
s t & \text { st } \\
-\phi y_{i t}+Y_{t} \lambda \geq 0 & -\phi y_{i s}+Y_{s} \lambda \geq 0 \\
x_{i t}-X_{t} \lambda \geq 0 & x_{i s}-X_{s} \lambda \geq 0 \\
\lambda \geq 0 & \lambda \geq 0
\end{array}
$$

\footnotetext{
${ }^{1}$ Malmquist TFV endeksinin hesaplanmasına ilişkin formülasyon Cingi ve Tarım 2000: 9 - 11'den özetlenerek alınmıştır.
} 


$$
\begin{array}{ll}
{\left[d^{t}\left(y_{s}, x_{s}\right)\right]^{-1}=\max _{\phi, \lambda} \phi} & {\left[d^{s}\left(y_{t}, x_{t}\right)\right]^{-1}=\max _{\phi, \lambda} \phi} \\
s t & \text { st } \\
-\phi y_{i s}+Y_{t} \lambda \geq 0 & -\phi y_{i t}+Y_{s} \lambda \geq 0 \\
x_{i s}-X_{t} \lambda \geq 0 & x_{i t}-X_{s} \lambda \geq 0 \\
\lambda \geq 0 & \lambda \geq 0
\end{array}
$$

Yukarıda tanımlanan uzaklık değerlerinin tüm dönemler ve gözlemler için hesaplanabilmesi, $n$ gözlem sayısını ve $t$ dönem sayısını göstermek üzere, $n(3 t-2)$ tane doğrusal programlama modelinin çözümünü gerektirmektedir.

\subsection{Veri Seti, Kısıtlar ve Program Seçimi}

Uygulamalı çalışmalarda en önemli kısıtlardan birisi KVB seçimidir. Karar birimlerinin üretim ve teknoloji bakımından birbirlerinin benzeri olmaları, bir başka ifadeyle homojen olmaları elde edilecek sonuçların anlamlı olması açısından çok önemlidir. Seçilen karar birimlerinin etkinliklerinin sağlıklı bir şekilde ölçülebilmesi için gerekli birim sayısının girdi ve çıktı sayısının en az üç katı olması gerektiğini savunanların yanı sıra, bu sayının en az yirmi olduğunu savunanlar da vardır. Uygulamada en çok karşılaşılan durum, seçilen karar biriminin girdi ve çıktı sayısının en az iki katı olması gerektiğidir (Behdioğlu ve Özcan, 2009: 303 - 304). Bu çerçevede Vassiloglou ve Giokas'ın sezgisel kuralı (Tarım, 2001:164) genel kabul gören yaklaşım olarak belirtilebilir. Bu sezgisel kural, şöyle ifade edilebilir: girdi sayısı $m$, çıktı sayısı da $p$ ise, karar birimi sayısı en az $(m+p) x 2$ olmalıdır. Bu kapsamda çalışmaya dâhil edilecek banka sayısına ilişkin değerlendirmenin girdi ve çıktı setinin belirlenmesiyle birlikte yapılması gerekmektedir.

Karar birimi sayısı dışında, bankalarla ilgili verimlilik çalışmaları açısından en önemli noktalardan birini de girdi ve çıktıların seçimi oluşturmaktadır. Literatürde hangi girdi ve çıktı değişkenlerinin kullanılacağına ilişkin bir fikir birliği bulunmamakla birlikte bazı değişkenler pek çok çalışmada ortak olarak karşımıza çıkmaktadır.

Girdi ve çıktıların seçiminde rol oynayacak temel farklılıklardan biri, kullanılacak yaklaşımın ne olduğu noktasında ortaya çıkmaktadır. Bankaların nasıl bir işletme olduğuna ilişkin kabule göre farklı yaklaşımlar benimsenmektedir. Buna göre bankaların verimlilik analizlerinde kullanılan üç farklı yaklaşım söz konusudur: Aracılık yaklaşımı, üretim yaklaşımı ve kâr yaklaşımı. Bunlardan hangisinin seçildiğine bağlı olarak girdi ve çıktı setinin tercih edilmelidir.

Öte yandan, modele çok fazla girdi ve çıktı değişkeninin eklenmesi, VZA yönteminin verimli ve verimsiz birimleri birbirinden ayırt etme yeteneğini düşürmektedir. Girdi ve çıktı sayılarının artırılabilmesi için karar birimlerinin sayısının da artması gerekmektedir (Yaşa, 2008: 59)

Literatürde, girdi ve çıktıların belirlenmesine dönük üç yaklaşım bulunmaktadır (Türker Kaya ve Doğan, 2005: 5): 
1) Üretim yaklaşımı: Bu yaklaşımda, bankalar işgücünü (çalışan sayısı/maliyeti) ve fiziksel sermayeyi (sabit varlıklar) kullanarak, mevduat ve kredi hesapları (hesap sayısı/işlem adedi) üreticisi birimler olarak ele alınmaktadır.

2) Aracılık yaklaşımı: $\mathrm{Bu}$ yaklaşımda mali kuruluşların tasarruf sahipleriyle yatırımcılar arasındaki geleneksel aracılık işlevinden hareket edilmektedir. Bankalar mevduat ve diğer yabancı kaynaklarını kredilere dönüştürmek için sermaye ve işgücü kullanan firmalar olarak değerlendirilmektedir. Bu yaklaşımda girdileri bankanın yabancı kaynakları (mevduat ve diğer yabancı kaynaklar veya bunlara yapılan faiz ödemeleri), işgücü ödemeleri, fiziksel sermaye (sabit varlıklar), çıktıları ise krediler ve diğer gelir getiren aktifler veya bunlara ait faiz gelirleri oluşturmakta ve girdi/çıktılar parasal büyüklükleri ile ölçülmektedir. Aracılık yaklaşımıyla üretim yaklaşımı arasındaki temel farklılık, aracılık yaklaşımında gelir getiren aktifler çıktı olarak değerlendirilirken, üretim yaklaşımında yükümlülük kalemleri de (temelde mevduat) çıktı olarak değerlendirilmektedir.

3) Kâr yaklaşımı: Bu yaklaşım, bankaların temel amacının kâr maksimizasyonu olmasından hareket etmektedir. Bunun sağlanması için bankalar gelirlerini artırmaya ve maliyetlerini azaltmaya çalışmaktadır. Bu yaklaşımda girdi olarak faiz dışı giderler (işletme giderleri ve diğer faiz dışı giderler), çıktı olarak ise net faiz geliri ve faiz dışı gelirler alınmaktadır.

Üretim yaklaşımı genelde şube etkinliğini değerlendirmede ve şubeler arası karşılaştırmalarda, aracılık yaklaşımı ise tüm sisteme yönelik değerlendirmelerde ya da sistemler arası karşılaştırmalarda yaygın olarak kullanılmaktadır.

Türkiye bankacılık sektörüne ilişkin verimlilik / etkinlik çalışmalarına bakıldığında, bu konuda belli bir girdi ve çıktı veri seti üzerinde fikir birliğinin oluşmadığı görülmektedir. Aşağıdaki tabloda Türkiye bankacılık sektörü üzerine yapılmış bazı çalışmaların kullandıkları girdi ve çıktı seti özetlenmiştir.

Tablo 3. Seçilmiş Bazı Çalışmalarda Kullanılan Girdi - Çıktı Seti

\begin{tabular}{|c|c|c|}
\hline "ÇALIŞMA & "GÍRDİLER & "ÇIKTILAR \\
\hline $\begin{array}{l}\text { Aracioğlu ve } \\
\text { Demirhan, } 2011\end{array}$ & $\begin{array}{l}\text { Mevduatlar / Toplam Aktifler } \\
\text { MDYK }^{2} \text { Toplam Aktifler } \\
\text { Faiz Giderleri / Toplam Aktifler } \\
\text { Faiz Dıș Giderler / Toplam Aktifler }\end{array}$ & $\begin{array}{l}\text { Toplam Kredi / Toplam Aktifler } \\
\text { Faiz Gelirleri / Toplam Aktifler }\end{array}$ \\
\hline Aydın, 2010 & $\begin{array}{l}\text { Personel Sayıs1 } \\
\text { Toplam Mevduatlar } \\
\text { Maddi Duran Varlıklar }\end{array}$ & $\begin{array}{l}\text { Toplam Krediler } \\
\text { Menkul Kıymetler Cüzdanı } \\
\text { Toplam Bilânço Dışı Kalemler }\end{array}$ \\
\hline BDDK, 2008 & $\begin{array}{l}\text { Sermaye } \\
\text { İsgücü } \\
\text { Mevduat } \\
\text { Diğer Yabancı Kaynaklar }\end{array}$ & Kredi \\
\hline
\end{tabular}

\footnotetext{
${ }^{2}$ MDYK $=$ Mevduat Dışı Yabancı Kaynaklar
} 


\begin{tabular}{|c|c|c|}
\hline ÇALIŞMA & GİRDİLER & ÇIKTILAR \\
\hline $\begin{array}{l}\text { BDDK, 2009; } \\
\text { BDDK, 2010 ve } \\
\text { BDDK, } 2011\end{array}$ & $\begin{array}{l}\text { Yabancı Kaynaklar / Toplam Aktifler } \\
\text { Faiz Giderleri / Toplam Aktifler } \\
\text { Faiz Dışı Giderler / Toplam Aktifler }\end{array}$ & $\begin{array}{l}\text { Toplam Krediler / Toplam Aktifler } \\
\text { Faiz Gelirleri / Toplam Aktifler } \\
\text { Faiz Dişı Gelirler / Toplam Aktifler }\end{array}$ \\
\hline Behdioğlu ve Özcan, 2009 & $\begin{array}{l}\text { Personel Sayı1s1 } \\
\text { Faiz Dış1 Giderler } \\
\text { Faiz Giderleri } \\
\text { Şube Sayıs1 } \\
\end{array}$ & $\begin{array}{l}\text { Toplam Mevduat } \\
\text { Toplam Kredi Miktarı } \\
\text { Net Kâr }\end{array}$ \\
\hline Budak, 2011 & $\begin{array}{l}\text { Şube Sayısı } \\
\text { Personel Sayısı } \\
\text { Faiz ve Faiz Dışı Giderler Toplamı }\end{array}$ & $\begin{array}{l}\text { Toplam Mevduat } \\
\text { Toplam Krediler } \\
\text { Faiz ve Faiz Dışı Gelirler Toplamı } \\
\text { Net Kâr }\end{array}$ \\
\hline $\begin{array}{l}\text { Cingi ve Tarım, } \\
2000\end{array}$ & $\begin{array}{l}\text { Toplam Aktifler } \\
\text { Toplam Giderler }\end{array}$ & $\begin{array}{l}\text { Toplam Kâr } \\
\text { Toplam Kredi } \\
\text { Toplam Mevduat } \\
\text { Kredi Geri Dönüş Oranı } \\
\end{array}$ \\
\hline Demir ve Gençtürk, 2006 & \begin{tabular}{|l|} 
İşgücü \\
Sermaye \\
Mevduatlar \\
\end{tabular} & $\begin{array}{l}\text { Krediler } \\
\text { Faiz Gelirleri } \\
\text { Faiz Diş1 Gelirler } \\
\end{array}$ \\
\hline Ekren ve Emiral, 2002 & $\begin{array}{l}\text { Toplam Mevduat ve Kısa Vadeli Borçlar } \\
\text { Toplam Maliyet }^{3}\end{array}$ & $\begin{array}{l}\text { Toplam Krediler } \\
\text { Diğer Gelir Getiren Aktifler }\end{array}$ \\
\hline Kök ve Ay, 2013 & $\begin{array}{l}\text { Personel Sayıs1 } \\
\text { Şube Sayisı } \\
\text { Faiz Giderleri } \\
\text { Toplam Aktif } \\
\end{array}$ & $\begin{array}{l}\text { Net Kâr } \\
\text { Toplam Krediler } \\
\text { Toplam Mevduat }\end{array}$ \\
\hline Köksal, 2001 & $\begin{array}{l}\text { Şube Say1sı } \\
\text { Personel Sayıs1 } \\
\text { Toplam Aktifler } \\
\text { Toplam Faiz Giderleri } \\
\end{array}$ & $\begin{array}{l}\text { Net Dönem Kârı } \\
\text { Toplam Krediler } \\
\text { Toplam Mevduat } \\
\text { Kredi Geri Dönüş Oranı } \\
\end{array}$ \\
\hline Öncü ve Aktaş, 2007 & \begin{tabular}{|l|} 
Personel Sayısı \\
Fiziki Sermaye \\
Ödünç Alınan Fonlar \\
\end{tabular} & $\begin{array}{l}\text { Toplam Krediler } \\
\text { Diğer Gelir Getirici Varlıklar }\end{array}$ \\
\hline Seyrek ve Ata, 2010 & \begin{tabular}{|l|} 
Toplam Mevduat \\
Faiz Gideri \\
Faiz Dışı Gider \\
\end{tabular} & $\begin{array}{l}\text { Toplam Kredi } \\
\text { Faiz Geliri } \\
\text { Faiz Dışı Gelir }\end{array}$ \\
\hline Şen, 2006 & $\begin{array}{l}\text { Toplam Mevduat } \\
\text { Toplam Gider }\end{array}$ & $\begin{array}{l}\text { Toplam Kâr } \\
\text { Toplam Kredi } \\
\text { Menkul Kıymetler Cüzdanı }\end{array}$ \\
\hline Türker Kaya ve Doğan, 2005 & $\begin{array}{l}\text { Üretim Yaklaşımına Göre: } \\
\text { Personel Giderleri / Toplam Aktifler } \\
\text { Diğer Faiz Dışı Giderler / Toplam Aktifler } \\
\text { Şube Başına Personel Sayısı } \\
\quad \text { Aracıllk Yaklaşımına Göre: } \\
\text { Mevduat / Toplam Aktifler } \\
\text { MDYK / Toplam Aktifler } \\
\text { Faiz Giderleri / Toplam Aktifler } \\
\text { Faiz Dışı Giderler / Toplam Aktifler }\end{array}$ & $\begin{array}{l}\text { Üretim Yaklaşımına Göre: } \\
\text { Toplam Mevduat / Toplam Aktifler } \\
\text { Toplam Krediler / Toplam Aktifler } \\
\\
\text { Aracıllk Yaklassımına Göre: } \\
\text { Toplam Krediler / Toplam Aktifler } \\
\text { Faiz Gelirleri / Toplam Aktifler }\end{array}$ \\
\hline Yaşa, 2008 & \begin{tabular}{|l|} 
Personel Sayıs1 \\
Sermaye \\
Toplam Aktifler \\
\end{tabular} & $\begin{array}{l}\text { Toplam Mevduat } \\
\text { Toplam Krediler } \\
\text { Net Kâr } \\
\end{array}$ \\
\hline
\end{tabular}

Kaynak: Bu çalışma için tarafımızdan derlenmiş olup, tabloda belirtilen çalışmaların bibliyografik künyeleri kaynakçada gösterilmiştir.

Tablodan da görüldüğü gibi Türkiye bankac1lık sektörüne ilişkin olarak gerçekleştirilen etkinlik çalışmalarında birbirinden oldukça farklı girdi ve çıktı setleri kullanılmıştır. Bu farklılığın temel bir

\footnotetext{
${ }^{3}$ Toplam Maliyet $=$ Faiz Gideri + Faiz Dışı Gider + Personel Gideri
} 
gerekçesi yapılan analizlerin farklı amaçlara yönelik olmasıdır. Bir diğer gerekçe olarak, her zaman aralığında ve her banka açısından homojen bir veri setine ulaşmanın güçlüğünden söz edilebilir.

Bununla birlikte, araştırmacıların yapmış olduğu tercihlere ilişkin olarak ileri sürdükleri savların, farklı bakış açılarıyla eleştiriye açık olduğunu da belirtmek gerekir. Bankalar üzerine etkinlik çalışmalarında daha önce de belirtildiği gibi aracılık, üretim ve kâr yaklaşımı olmak üzere üç farklı yaklaşım geliştirilmiştir. Bu yaklaşımlardan birinin girdi olarak aldığı bir değişken, diğer bir yaklaşımda çıtı olarak kabul edilebilmektedir. Özellikle mevduatların konumu tartışmalıdır. Bankaların topladıkları mevduatlar, üretim yaklaşımında çıktı olarak değerlendirilirken, aracılık yaklaşımında girdi olarak değerlendirilmektedir.

Mevduatlara ödenen faiz tutarlarının bazı çalışmalarda maliyet unsuru olarak girdi fiyatı şeklinde modele dâhil edilebildiği bazılarında ise mevduatların bir likidite unsuru olarak algılanması nedeniyle modellere çıktı olarak dâhil edilebildiği görülmektedir (Berger ve Humphrey, 1997: 32).

İlgili literatür taraması çerçevesinde ve homojen istatistik temini bakımından çalışmamız kapsamında bilanço bilgilerinin esas alınması yoluna gidilmiştir. Buna göre bankaların esas olarak finansal aracılık fonksiyonları dikkate alınarak; belli giderler karşılığında pasif kaynaklar elde edip, bunlarla gelir getirici aktiflere sahip oldukları ilişkisinden hareket edilmiştir.

Bu kapsamda belirlenen girdi değişkenleri şunlardır:

- Toplam Mevduatlar,

- Mevduat Dışı Kaynaklar.

Bu kapsamda belirlenen çıktı değişkenleri ise şunlardır:

- Toplam Finansal Varlıklar,

- Krediler ve Alacaklar,

- Duran Aktifler.

Girdi değişkenleri arasında yer alan mevduat dışı kaynaklar kapsamında alınan krediler, para piyasalarına borçlar, ihraç edilen menkul kıymetler yer almaktadır. Geleneksel olarak bankalar, mevduatları temel fon temin etme kaynağı olarak görmekteydiler. Ancak özellikle son iki yılda ihraç edilen menkul kıymetler yoluyla fon temini giderek önem kazanmıştır. Çıktı değişkenleri arasında yer alan toplam finansal varlıklar kalemi içinde satılmaya hazır menkul kıymetler yanında vadeye kadar tutulacak menkul kıymetler ile riskten korunma amacıyla elde edilmiş finansal varlıklar da bulunmaktadır.

Çalışmamızda mevduat bankası olarak faaliyet gösteren bankalar; sermayelerine göre (kamu, özel ve yabancı sermayeli bankalar) grup bazında ve tekil banka bazında olmak üzere iki boyutta incelenmiştir. Bu ayrım yoluyla yabancı bankaların hem grup olarak etkinlik gelişimi hem de bazı 
bankaların inceleme dönemi içinde özel sermayeli banka statüsünden yabancı sermayeli banka statüsüne geçmelerinin etkinlikleri üzerinde bir farklılık yaratıp yaratmadığı görülebilecektir.

Tablo 4: Türkiye Bankacılık Sistemindeki Banka Sayıları (31.12.2012 itibariyle)

\begin{tabular}{|c|c|c|c|c|}
\hline & \multicolumn{4}{|c|}{ Banka Sayıları } \\
\hline Türkiye Bankacılık Sistemi Toplamı & & & & 45 \\
\hline ---Mevduat Bankaları & & & 32 & \\
\hline *Kamusal Sermayeli Mevduat Bankaları & & 3 & & \\
\hline *Özel Sermayeli Mevduat Bankaları & & 2 & & \\
\hline *Tasarruf Mevduatı Sigorta Fonuna Devredilen Bankalar & & 1 & & \\
\hline *Yabancı Sermayeli Mevduat Bankaları & & 6 & & \\
\hline -Türkiye'de Kurulmuş Yabancı Sermayeli Bankalar & 10 & & & \\
\hline - Türkiye'de Şube Açan Yabancı Sermayeli Bankalar & 6 & & & \\
\hline --Kalkınma ve Yatırım Bankaları & & & 13 & \\
\hline *Kamusal Sermayeli Kalkınma ve Yatırım Bankaları & & 3 & & \\
\hline *Özel Sermayeli Kalkınma ve Yatırım Bankaları & & 6 & & \\
\hline *Yabancı Sermayeli Kalkınma ve Yatırım Bankaları & & 4 & & \\
\hline
\end{tabular}

Kaynak: TBB web sitesinden 31.12.2012 tarihi itibariyle yapılan sorgulamadan derlenmiştir.

Tablo 4 ile Türkiye Bankacılık Sistemi bünyesinde yer alan banka sayıları, banka sermayelerinin yapısına göre verilmiştir. Türkiye Bankalar Birliği’nin sınıflandırmasına göre, 31.12.2012 tarihi itibariyle, Türkiye'de 16'sı mevduat bankas1, 4'ü kalkınma ve yatırım bankas1 statüsünde toplam 20 yabancı sermayeli banka faaliyet göstermektedir. Toplam 45 bankanın bulunduğu Türkiye Bankacılık Sistemi'nde 32 mevduat bankası ve 13 kalkınma ve yatırım bankası bulunmaktadır. Buradan hareketle Türkiye'de bankacılık sektöründe mevduat bankalarının ağırlı̆̆ının daha fazla olduğu belirtilebilir.

Türkiye bankacılık sektöründe toplam olarak 45 banka faaliyet göstermekle birlikte, bu bankaların aktif büyüklüklerine göre bir değerlendirme yapıldığında ilk 10 büyük banka sektör aktiflerinin yüzde 87,17'sini oluşturmaktadır. Bu nedenle, veri seti ile ilgili tartışmalar da dikkate alınarak, çalışmamız kapsamında incelenen mevduat bankalarının sayısının sınırlandırılmasının yararlı olacağı düşünülmüştür.

Çalışmamızda yapılacak uygulama kapsamına alınan bankaların Türkiye bankacılık sektörü toplam aktifleri içindeki payları aşağıdaki Tablo 5'de verilmiştir. Aralık 2012 itibariyle sektör aktifleri içindeki payı yüzde 1'in altında olan bankalar çalışma kapsamı dışında bırakılmıştır. Zira bu bankaların faaliyet alanları itibariyle butik banka şeklinde çalışıyor olması, etkinlik açısından uç değerlerin ortaya çıkması ve dolayısıyla da sektör içinde ağırlığı bulunan bankalara ilişkin değerlendirmeleri çarpıtmaları olasılı̆̆g mevcuttur. Tablodan da görüleceği gibi uygulama kapsamındaki bankaların toplam aktifleri, sektör toplam aktifi içinde Aralık 2012 itibariyle yüzde 92,2 gibi çok yüksek bir orana ulaşmaktadır. Buradan da anlaşılacağı gibi, çalışma kapsamı dışında bırakılan bankaların toplam aktif içindeki payları oldukça düşüktür. 
Tablo 5: Analiz Kapsamındaki Bankaların Sektör Aktif Büyüklüğü İçindeki Payı (\%)

\begin{tabular}{|l|c|c|c|c|c|c|c|c|}
\hline Banka Adı & Sermaye & $\mathbf{2 0 0 6}$ & $\mathbf{2 0 0 7}$ & $\mathbf{2 0 0 8}$ & $\mathbf{2 0 0 9}$ & $\mathbf{2 0 1 0}$ & $\mathbf{2 0 1 1}$ & $\mathbf{2 0 1 2}$ \\
\hline Türkiye İş Bankası & Özel & 15,5 & 14,3 & 13,8 & 14,2 & 13,7 & 13,9 & 13,5 \\
TC Ziraat Bankas1 & Kamu & 14,8 & 14,4 & 14,8 & 15,6 & 15,7 & 13,8 & 12,5 \\
Türkiye Garanti Bankas1 & Özel & 10,4 & 12,0 & 12,6 & 13,2 & 12,9 & 12,6 & 12,3 \\
Akbank & Özel & 11,8 & 12,2 & 12,1 & 11,9 & 11,8 & 11,5 & 12,0 \\
Yap1 ve Kredi Bankası & Özel & 10,1 & 9,0 & 9,0 & 8,1 & 8,8 & 9,3 & 9,4 \\
Türkiye Halk Bankas1 & Kamu & 7,1 & 7,2 & 7,2 & 7,6 & 7,6 & 7,9 & 8,3 \\
Türkiye Vakıflar Bankası & Kamu & 7,6 & 7,6 & 7,4 & 8,1 & 7,7 & 7,7 & 8,1 \\
Finans Bank & Yabanc1 & 3,7 & 3,7 & 3,8 & 3,7 & 4,0 & 4,0 & 4,2 \\
Denizbank & Yabanc1 & 2,4 & 2,7 & 2,7 & 2,7 & 2,9 & 3,1 & 3,4 \\
Türk Ekonomi Bankası & Özel & 1,7 & 2,1 & 2,1 & 1,9 & 2,0 & 3,3 & 3,4 \\
HSBC Bank & Yabanc1 & 2,1 & 2,4 & 2,1 & 1,7 & 1,8 & 2,1 & 1,9 \\
ING Bank (*) & Yabanc1 & 2,4 & 2,2 & 2,3 & 1,9 & 1,8 & 1,8 & 1,9 \\
Şekerbank & Özel & 0,8 & 1,1 & 1,1 & 1,1 & 1,2 & 1,2 & 1,1 \\
TOPLAM & & 90,4 & 90,9 & 91 & 91,7 & 91,9 & 92,2 & 92,2 \\
\hline
\end{tabular}

Kaynak: Türkiye Bankalar Birliği, Bankalarımız Kitabı, ilgili yıllardan derlenmiştir.

(*) BDDK'nın 12.12.2007 tarihli kararıla Oyak Bank, 07.07.2008 tarihinden itibaren geçerli olmak üzere ING Bank unvanını almıştır. Bunun için ING Bank’ın söz konusu devir öncesi verileri Oyak Bank'a aittir.

Analiz kapsamında ele alınmasını uygun gördüğümüz banka sayısı 13, kullanılacak girdi ve çıktı sayısı da 5’tir. Bu durumda yukarıda yer verdiğimiz tartışmada ele alındığı gibi genel bir kural olarak belirlenmiş olan, KVB sayısının (girdi sayısı + çıktı sayısı)x2 yaklaşımına uygun bir yapı oluşturulmuştur.

Çalışmamızda bilgisayar programı olarak Win4DEAP versiyon 1.1.2 kullanılmıştır. Win4DEAP, Tim Coelli tarafından geliştirilen ve pek çok VZA araştırmasında kullanılan DEAP isimli paket programın, Michel Deslierres tarafından Windows uyumlu olarak geliştirilmiş halidir. VZA için kullanılan Win4DEAP paket programı "free software" olarak dağıtılmaktadır.

\subsection{Uygulama Sonuçları}

Daha önce belirtildiği gibi Türkiye'de faaliyet gösteren yabancı sermayeli bankaların verimlilik düzeylerindeki gelişimi ortaya koymaya çalıştığımız bu uygulama, sermaye mülkiyetleri bazında ve banka bazında olmak üzere iki aşamada gerçekleştirilmiştir. Aşağıda öncelikle grup bazında analizin sonuçları, ardından banka bazında analizin sonuçları verilmiştir.

\subsubsection{Sermaye Mülkiyetine Göre Banka Gruplarında Toplam Faktör Verimliliği Değişimi}

Banka grupları bazında hesapladığımız toplam faktör verimliliği değişimleri inceleme dönemi itibariyle Tablo 6'da verilmiştir. Buradaki sermaye mülkiyetine göre gruplandırmada küçük / büyük ölçekli banka ayrımına gidilmemiş; grupta yer alan tüm bankaların girdi ve çıktıları kullanılarak Malmquist Toplam Faktör Verimliliği Endeksi hesaplanmıştır.

Tabloda yer alan sonuçlarda dikkati çeken ilk önemli nokta dönem ortalaması olarak en yüksek endeks değerine yabancı, en düşük endeks değerine ise kamu bankalarının sahip olmasıdır. Bu durum 
toplam faktör verimliliği göstergesi boyutuyla inceleme döneminde yabancı bankaların daha etkin olduğunu ortaya koymaktadır.

Bir önceki yıla göre TFV değişimi 2008 ve 2011 yıllarında her üç grup için de negatif olmuştur. Bu iki yılda ortalama olarak TFV sırasıyla \%1,29 ve \%1,65 oranlarında azalış göstermiştir. Bu durum, 2008 yılının ABD’de başlayan Mortgage sektörü kaynaklı küresel finans kriziyle; 2011 yılının da TCMB tarafından ekonomiyi soğutma amaçlı olarak uygulanan sıkı para politikasının bankacılık sektörüne etkileriyle bağlantılıdır ve bankacılık sektörü açısından zorlu yıllar olduğu gerçeğiyle örtüşmektedir.

Diğer taraftan TFV endeksinde 2007 yılında \%8,2, 2009 y1lında \%2,1, 2010 y1lında $\% 0,8$ ve 2012 yılında \%7,0 oranında artış yaşanmıştır. Endeks değerlerinin gerilediği yıllarla karşılaştırıldı̆̆ında bu yıllardaki toplam faktör verimliliği artışının oldukça yüksek olduğu görülmektedir.

Tabloda dikkati çeken önemli bir nokta da verilerde 2010 yılında yaşanan gelişmelerdir. Nitekim sadece bu yılda yabancı sermayeli bankaların endeks değeri hem kamu hem de yerli özel bankalardan daha düşük kalmıştır. 2009 yılında ise yabancı sermayeli bankaların endeks değeri kamu bankalarından yüksek, yerli özel bankalardan düşük olmuştur. Merkez Bankasının cari açığı azaltmak ve bu amaçla iç talebi daraltmak için daha çok zorunlu karşılık oranlarını kullanarak uyguladığ daraltıcı para politikalarından ise toplam faktör verimliliği boyutundan kamu ve özel sermayeli bankalar önemli oranda olumsuz etkilenirken yabancı bankaların oldukça sınırlı oranda etkilendiği görülmektedir. Bu durum yabancı bankaların küresel gelişmelerden Türkiye içindekilere oranla daha fazla etkilendiği anlamına gelmektedir.

Tablo 6. Banka Grupları Bazında Malmquist Toplam Faktör Verimliliği Endeksleri

\begin{tabular}{|l|c|c|c|c|}
\hline & $\begin{array}{c}\text { Kamu } \\
\text { Sermayeli } \\
\text { Bankalar }\end{array}$ & $\begin{array}{c}\text { Özel } \\
\text { Sermayeli } \\
\text { Bankalar }\end{array}$ & $\begin{array}{c}\text { Yabancı } \\
\text { Sermayeli } \\
\text { Bankalar }\end{array}$ & Ortalama \\
\hline $2006-2007$ & 1,066 & 1,026 & 1,158 & 1,082 \\
\hline $2007-2008$ & 0,835 & 0,838 & 0,944 & 0,871 \\
\hline $2008-2009$ & 0,947 & 1,089 & 1,032 & 1,021 \\
\hline $2009-2010$ & 1,081 & 0,984 & 0,962 & 1,008 \\
\hline $2010-2011$ & 0,718 & 0,845 & 0,960 & 0,835 \\
\hline $2011-2012$ & 1,074 & 1,028 & 1,108 & 1,070 \\
\hline Ortalama TFVE & 0,943 & 0,963 & 1,024 & -- \\
\hline
\end{tabular}

NOT: Uygulama kapsamında verilen ortalama değerler aksi belirtilmedikçe, geometrik ortalama yöntemine göredir.

Banka grupları bazında TFV değişimi biraz daha detaylı olarak incelendiğinde; 2007, 2008, 2011 ve 2012 yıllarında yabancı sermayeli bankalar grubunun diğer gruplardan daha iyi performans gösterdiği dikkati çekmektedir. Kamu sermayeli bankalar grubu 2010 yılında, özel sermayeli bankalar 
grubu da 2009 yılında olmak üzere birer yıl diğer gruplardan daha iyi performans göstermiştir. Yabancı sermayeli bankaların TFV değişıimi, 2007 - 2012 yılında sırasıyla \%15,8; -\%5,6; \%3,2; $\% 3,8 ;-\% 4,0$ ve \%10,8 olmuştur. Bir başka ifadeyle bir önceki yıla göre TFV değişimi üç yıl negatif ve üç yıl da pozitif oranlarda gerçekleşmiştir. Buna rağmen dönem ortalaması olarak TFV \%2,4 oranında artış göstermiştir. Yabancı sermayeli bankalardaki TFV artışına karşılık, dönem ortalaması olarak kamu sermayeli bankalarda \%5,7 ve özel sermayeli bankalarda \%3,7 oranında azalış söz konusudur.

\subsubsection{Banka Bazında Toplam Faktör Verimliliği Değiş̧imi}

Bankalar bazında TFV değişimi aşağıdaki Tablo 7'de yer alan 2006 - 2012 dönemi için hesaplanan Malmquist TFV Endeksleri verileri çerçevesinde incelenmiştir. Analiz kapsamında yer alan 13 bankanın Malmquist TFV Endeksi değerlerinin yıllara göre ortalamalarını değerlendirdiğimizde bir önceki yıla göre toplam faktör verimliliklerinde 2007, 2009 ve 2012 y1llarında artış; 2008, 2010 ve 2011 yıllarında azalış olduğunu görmekteyiz. En yüksek standart sapmanın olduğu yıl 0,153 ile 2011 yılıdır. 2011 yılında TFV Endeksi bir önceki yıla göre ortalama olarak \%12,7 azalmıştır. Bu azalışta en büyük payın Türkiye Cumhuriyeti Ziraat Bankası'nın TFVE değerindeki \%51'lik azalışta olduğu görülmektedir.

Yıllar bazında bakıldığında 2007 yılında \%27,2'lik artışla ING Bank'ın, 2008 yılında \%14,3'lük artışla Şekerbank'ın, 2009 yılında \%21,8'lik artışla Türkiye İş Bankası'nın, 2010 yılında \%18,1'lik artışla Türkiye Cumhuriyeti Ziraat Bankası'nın, 2011 yılında \%7,8'lik artışla Türk Ekonomi Bankası'nın, 2012 yılında ise \%28,1'lik artışla yine Şekerbank'ın en yüksek toplam faktör verimliliği artışı sağladıkları görülmektedir. Toplam Faktör Verimliliği Endeksinde en düşük artış (bazı yıllarda en yüksek azalış) görülen bankalara bakıldığında 2007 yılında \%2,1'lik azalışla HSBC Bank, 2008 yılında \%38,6'lık azalışla Türkiye Cumhuriyeti Ziraat Bankası, 2009 yılında \%1,7'lik azalışla Denizbank, 2010 yılında \%23'lük azalışla Şekerbank, 2011 yılında \%51'lik azalışla Türkiye Cumhuriyeti Ziraat Bankası ve 2012 yılında \%4,3'lük azalışla Finans Bank dikkati çekmektedir.

Buradan hareketle TFV endeksindeki yıldan yıla ortaya çıkan değişimlerin banka bazında oldukça dalgalı bir seyir gösterdiği ifade edilebilir. Ortalamalara bakıldığında da aynı durumun varlığı dikkati çekmektedir. 2007 yılından 2012 yılında kadar, 13 bankanın ortalaması olarak TFVE değişim oranları sırasıyla şöyledir: \%9,1; -\%6,4; \%6,7; -\%4,1; -\%12,7; \%7,1. En yüksek artış \%9,1 ile 2007, en yüksek azalış ise -\%12,7 ile 2011 yılında gerçekleşmiştir. 
Tablo 7. Malmquist Toplam Faktör Verimliliği Endeksleri (2006 - 2012)

\begin{tabular}{|l|c|c|c|c|c|c|}
\hline & $\mathbf{2 0 0 6}-$ & $\mathbf{2 0 0 7}-$ & $\mathbf{2 0 0 8}-$ & $\mathbf{2 0 0 9 -}$ & $\mathbf{2 0 1 0 -}$ & $\mathbf{2 0 1 1}-$ \\
$\mathbf{2 0 0 7}$ & $\mathbf{2 0 0 8}$ & $\mathbf{2 0 0 9}$ & $\mathbf{2 0 1 0}$ & $\mathbf{2 0 1 1}$ & $\mathbf{2 0 1 2}$ \\
\hline Akbank & 1,074 & 0,895 & 1,188 & 0,966 & 0,884 & 0,984 \\
\hline Denizbank & 1,222 & 1,064 & 0,983 & 0,981 & 0,966 & 0,987 \\
\hline Finans Bank & 1,183 & 0,989 & 1,064 & 0,851 & 0,981 & 0,957 \\
\hline HSBC Bank & 0,979 & 0,945 & 1,048 & 0,814 & 0,977 & 1,086 \\
\hline ING Bank & $\mathbf{1 , 2 7 2}$ & 0,978 & 1,039 & 1,015 & 0,986 & 1,000 \\
\hline Şekerbank & 1,092 & $\mathbf{1 , 1 4 3}$ & 1,170 & 0,770 & 0,923 & $\mathbf{1 , 2 8 1}$ \\
\hline Türk Ekonomi Bankas1 & 1,000 & 0,969 & 1,063 & 1,027 & $\mathbf{1 , 0 7 8}$ & 1,037 \\
\hline Türkiye Cumhuriyeti Ziraat Bankası & 1,208 & 0,614 & 1,012 & $\mathbf{1 , 1 8 1}$ & 0,490 & 1,110 \\
\hline Türkiye Garanti Bankası & 0,993 & 1,025 & 1,007 & 1,045 & 0,965 & 1,052 \\
\hline Türkiye Halk Bankas1 & 0,982 & 0,969 & 1,034 & 1,035 & 0,806 & 1,192 \\
\hline Türkiye İş Bankas1 & 0,989 & 0,749 & $\mathbf{1 , 2 1 8}$ & 1,006 & 0,735 & 1,096 \\
\hline Türkiye Vakıflar Bankas1 & 1,072 & 0,966 & 1,043 & 1,067 & 0,970 & 0,996 \\
\hline Yapı ve Kredi Bankas1 & 1,181 & 0,987 & 1,038 & 0,800 & 0,783 & 1,199 \\
\hline Ortalama & 1,091 & 0,936 & 1,067 & 0,959 & 0,873 & 1,071 \\
\hline Maksimum & 1,272 & 1,143 & 1,218 & 1,181 & 1,078 & 1,281 \\
\hline Minimum & 0,979 & 0,614 & 0,983 & 0,770 & 0,490 & 0,957 \\
\hline Standart Sapma & 0,105 & 0,134 & 0,074 & 0,122 & 0,153 & 0,099 \\
\hline TFV Değişimi (Ortalama) & $\% 9,1$ & $-\% 6,4$ & $\% 6,7$ & $-\% 4,1$ & $-\% 12,7$ & $\% 7,1$ \\
\hline
\end{tabular}

Banka bazında ortalamalara baktığımızda, 2006 yılından 2012 yılına kadar Toplam Faktör Verimliliği Endeksi değişiminde en yüksek ortalamaya 1,049 ile Şekerbank, en düşük ortalamaya 0,886 ile Türkiye Cumhuriyeti Ziraat Bankası sahiptir. Bir başka ifadeyle 2006 yılından 2012 yılına kadar Şekerbank TFV'ni her yı1 \%4,9 oranında artırmışken, Türkiye Cumhuriyeti Ziraat Bankası aynı dönemde her yıl \%11,4 oranında azaltmıştır. Dolayısıyla verimlilik düzeyinin değişimi açısından bankalar bazında önemli farklılıkların olduğunu söylemek mümkündür.

Tablo 8. 2006 - 2012 Dönemi Ortalama Malmquist TFV Endeksleri

\begin{tabular}{|c|c|c|c|}
\hline & $\begin{array}{l}\text { Sermaye } \\
\text { Mülkiyeti }\end{array}$ & Ortalama & $\begin{array}{c}\text { Grup } \\
\text { Ortalaması }\end{array}$ \\
\hline Türkiye Cumhuriyeti Ziraat Bankası & Kamu & 0,886 & \multirow{3}{*}{0,965} \\
\hline Türkiye Halk Bankası & Kamu & 0,996 & \\
\hline Türkiye Vakıflar Bankası & Kamu & 1,018 & \\
\hline Akbank & Özel & 0,993 & \multirow{6}{*}{1,002} \\
\hline Şekerbank & Özel & 1,049 & \\
\hline Türk Ekonomi Bankası & Özel & 1,028 & \\
\hline Türkiye Garanti Bankası & Özel & 1,014 & \\
\hline Türkiye İş Bankası & Özel & 0,949 & \\
\hline Yap1 ve Kredi Bankası & Özel & 0,984 & \\
\hline Denizbank & Yabanc1 & 1,030 & \multirow{4}{*}{1,011} \\
\hline Finans Bank & Yabanc1 & 0,999 & \\
\hline HSBC Bank & Yabanc1 & 0,971 & \\
\hline ING Bank & Yabanc1 & 1,044 & \\
\hline Ortalama & & 0,996 & \\
\hline
\end{tabular}

Tablo 8'den görüldüğü gibi kamu sermayeli bankaların yıllık ortalama \%3,5 oranında TFV azalışına karşılık; özel sermayeli bankaların yıllık ortalama \%0,2'lik, yabancı sermayeli bankaların yıllık ortalama \%1,1'lik TFV artışı sağlamıştır. Bu sonuç, yukarıda grup bazında yapılan analiz 
sonuçlarıyla tutarlı olarak, yabancı sermayeli bankaların daha yüksek TFV artışına sahip olduğunu göstermektedir.

Daha önce açıklanmış olduğu gibi Toplam Faktör Verimliliğini belirleyen iki alt bileşen mevcuttur: Teknolojik etkinlik ve teknolojik değişme. Teknolojik etkinlik endeksi de pür ekonomik etkinlik endeksi ve ölçek etkinliği endeksi şeklinde iki alt bileşene ayrılabilmektedir. Buna göre bir bankanın toplam faktör verimlilik endeksini incelerken bu alt bileşenleri de dikkate almak yararlı olacaktır. Bu amaçla, banka bazında Toplam Faktör Verimliliği Endeksinin alt bileşenleri, 2006 2012 dönemi ortalaması olarak, Tablo 9'da verilmiştir.

Tablodan görüldüğü gibi tüm bankalar için TFV endeksindeki gerek gerilemede gerekse iyileşmede, teknolojik değişimin etkili olduğu dikkati çekmektedir. Nitekim 13 bankanın 13'ünde de teknolojik değişim için 1'den farklı değer hesaplanmışken; 13 bankanın 6'sında teknik etkinlik değişimi için 1'den farklı değer hesaplanmıştır. Bunun yanında teknolojik değişim TFV üzerine genellikle olumsuz etkide bulunurken, teknik etkinlik değişimi olumlu etkide bulunmaktadır. Üstelik teknolojik değişimin etkisi, teknik etkinlik değişiminin etkisinden daha güçlü olduğu da ortalamadan görülmektedir. Buradan hareketle Türkiye'de faaliyet gösteren ve analiz kapsamına alınan mevduat bankalarının etkin üretim sınır eğrisini yakalama (catching - up) açısından olumlu gelişmeler sağlayabildiklerini, ancak bu etkinin olumluluğunu etkin sınır eğrisindeki kaymanın bertaraf ettiğini belirtebiliriz.

TFV ortalama değerlerini banka bazında incelediğimizde, teknik etkinlik değişimi açısından yıllık ortalama \%1,4'lük artışla ING Bank'ın öne çıktığını; teknolojik değişim açısından yıllık ortalama \%4,9'luk artışla Şekerbank'ın öne çıktığını görmekteyiz. TFV değeri üzerinde etkili olan iki temel alt bileşenin olumsuz etki yaptığı banka örneklerine baktığımızda ise teknik etkinlik değişiminde y1llık ortalama \%1,4'lük gerilemeyle HSBC Bank'ın; teknolojik değişimde yıllık ortalama \%11,4'lük gerilemeyle Ziraat Bankası'nın öne çıktığını görmekteyiz.

Kamu sermayeli bankalar arasında TFV açısından öne çıkan Türkiye Vakıflar Bankası ortalama yıllık \% 1,8 oranında toplam faktör verimlilik artışı sağlamıştır. Bu gelişmenin gerisinde büyük ölçüde teknolojik değişme endeksi yer almaktadır. Diğer kamu sermayeli bankalarda da alt bileşenler açısından benzer bir durum görülmekle birlikte, Ziraat ve Halk bankalarında TFV azalışı söz konusudur. Buradan hareketle TFV artışında da azalışında da teknolojik değişmenin etkili olduğu ifade edilebilir.

Özel sermayeli bankalar arasında TFV endeksinde azalış olan üç banka mevcuttur: Yıllık ortalama \%5,1 azalışla Türkiye İş Bankası, \%1,6 azalışla Yapı ve Kredi Bankası ve \%0,7 azalışla Akbank TFV endeksi açısından en kötü performansa sahip olan bankalardır. Her üç banka için de teknik etkinlik endeksi 1,000 değerini almışken TFV endeksindeki azalışın ardında teknolojik değişme endeksi yer almaktadır. TFV endeksinde artış olan banka sayısı da üçtür: Yıllık ortalama \%4,9 artışla 
Şekerbank, \%2,8 artışla Türk Ekonomi Bankası ve \%1,4 artışla Türkiye Garanti Bankası Bu bankalardan Şekerbank bu TFV artışını tamamıyla teknolojik değişme endeksiyle sağlamışken, Türk Ekonomi Bankası'nın TFV artışı daha dengeli bir alt bileşen yapısına sahiptir.

Tablo 9. 2006 - 2012 Dönemi Ortalama Malmquist TFV Endekslerinin Bileşenleri

\begin{tabular}{|c|c|c|c|c|c|c|}
\hline & $\begin{array}{c}\text { Sermaye } \\
\text { Mülkiyet } \\
\text { i }\end{array}$ & $\begin{array}{c}\text { Teknik } \\
\text { Etkinlik } \\
\text { Değişim } \\
\text { i } \\
(\mathbf{1 = 3 x 4 )} \\
\end{array}$ & $\begin{array}{c}\text { Teknoloji } \\
\text { k } \\
\text { Değişim } \\
(2) \\
\end{array}$ & $\begin{array}{c}\text { Pür } \\
\text { Teknik } \\
\text { Etkinlik } \\
\text { Değişimi } \\
\text { (3) }\end{array}$ & $\begin{array}{c}\text { Ölçek } \\
\text { Etkinliğ } \\
\text { i } \\
\text { Değişim } \\
\text { i } \\
(4) \\
\end{array}$ & $\begin{array}{c}\text { Toplam } \\
\text { Faktör } \\
\text { Verimliliği } \\
\text { Endeksi } \\
(5=1 \times 2) \\
\end{array}$ \\
\hline $\begin{array}{l}\text { Türkiye Cumhuriyeti Ziraat } \\
\text { Bankası }\end{array}$ & Kamu & 1,000 & 0,886 & 1,000 & 1,000 & 0,886 \\
\hline Türkiye Halk Bankası & Kamu & 1,000 & 0,996 & 1,000 & 1,000 & 0,996 \\
\hline Türkiye Vakıflar Bankası & Kamu & 1,001 & 1,017 & 0,999 & 1,002 & 1,018 \\
\hline Akbank & Özel & 1,000 & 0,993 & 1,000 & 1,000 & 0,993 \\
\hline Şekerbank & Özel & 1,000 & 1,049 & 1,000 & 1,000 & 1,049 \\
\hline Türk Ekonomi Bankası & Özel & 1,012 & 1,016 & 1,008 & 1,004 & 1,028 \\
\hline Türkiye Garanti Bankas1 & Özel & 0,999 & 1,015 & 1,000 & 0,999 & 1,014 \\
\hline Türkiye İş Bankası & Özel & 1,000 & 0,949 & 1,000 & 1,000 & 0,949 \\
\hline Yap1 ve Kredi Bankası & Özel & 1,000 & 0,984 & 1,000 & 1,000 & 0,984 \\
\hline Denizbank & Yabanc1 & 1,013 & 1,017 & 1,017 & 0,996 & 1,030 \\
\hline Finans Bank & Yabanc1 & 1,000 & 0,999 & 1,000 & 1,000 & 0,999 \\
\hline HSBC Bank & Yabancı & 0,986 & 0,985 & 1,000 & 0,986 & 0,971 \\
\hline ING Bank & Yabanc1 & 1,014 & 1,029 & 1,013 & 1,001 & 1,044 \\
\hline Ortalama & & 1,002 & 0,994 & 1,003 & 0,999 & 0,996 \\
\hline
\end{tabular}

Yabancı sermayeli bankaların TFV ortalamalarını incelediğimizde, yukarıdaki tablodan görüldüğü gibi dört bankanın ikisinde TFV azalışı, ikisinde TFV artışı dikkati çekmektedir. Yıllık ortalama \%4,4 oranında TFV artışıyla ING Bank, \%3,0 oranında TFV artışılla Denizbank olumlu performans gösteren bankaları oluştururken; yıllık ortalama \%3,9 TFV azalışıyla HSBC Bank ve \%0,1 TFV azalışıly Finans Bank olumsuz performans gösteren bankalardır. Bununla birlikte Finans Bank'ın TFV azalışııın, 13 banka ortalamasının altında kaldığı, bir başka ifadeyle 13 banka ortalamasından daha olumlu bir performans gösterdiği de belirtilmelidir.

Yabancı sermayeli bankalardan ING Bank ve Denizbank'1n gösterdiği TFV artışı şeklindeki olumlu performansın alt bileşenlerinde teknolojik değişme endeksinin etkisi biraz daha fazla olmakla birlikte, göreli olarak daha dengeli bir alt bileşen yapısına sahip oldukları da ifade edilebilir. Nitekim ING Bank’taki \%4,4'lük TFV artışının yaklaşık üçte ikilik kısmı teknolojik değişme endeksinden, yaklaşık üçte birlikte kısmı da teknik etkinlik endeksinden kaynaklanmaktadır. Buna karşılık Denizbank’taki \%3,0'lük TFV artışının yarısından biraz fazlası teknolojik değişme endeksinden, yarısından biraz azı da teknik etkinlik endeksinden kaynaklanmaktadır. Benzer bir durum Türk Ekonomi Bankası için de söz konusu olup, diğer bankalarda TFV değişiminin alt bileşenlerinde teknik etkinlik endeksinin etkili olmaması ve dolayısıyla daha dengesiz alt bileşen yapısının varlığı üzerinde durulması gereken önemli bir sonuçtur.

Sonuç olarak 2006 - 2012 döneminde etkinlik düzeylerinin dinamik analizi yapılan kamu, özel ve yabancı sermayeli bankalar şeklindeki üç banka grubu içinde yabancı sermayeli bankalar grubunun 
daha etkin faaliyet gösterdiği, kamu ve özel sermayeli banka grubunda ise etkinsiz bir faaliyet döneminin yaşandığı ifade edilebilir. İnceleme döneminde yabancı sermayeli bankalar yıllık ortalama \%2,4'lük TFV artışı sağlamışken, özel sermayeli bankalar grubunda yıllık ortalama \%3,7’lik TFV azalışı, kamu sermayeli bankalar grubunda yıllık ortalama \%5,7'lik TFV azalışı söz konusudur.

Tekil banka bazındaki analiz sonuçlarımıza göre de özetle kamu sermayeli bankalar içinde Türkiye Vakıflar Bankası'nın, özel sermayeli bankalar içinde Şekerbank'ın ve yabancı sermayeli bankalar içinde de ING Bank'ın olumlu performanslarıyla daha etkin faaliyet gösteren bankalar olduğunu belirtebiliriz.

Tablo 9'da banka bazında toplam faktör verimliliği endeksinin bileşenleri değerlendirilmişti. Ancak bu değerlendirme 2006 - 2012 döneminin TFV endeksi ortalaması kullanılmıştır. Dolayısıyla yabancı sermayeli mevduat bankalarının TFV düzeyinde dönem içinde ortaya çıkan gelişmeleri, söz konusu tablodan izlemek söz konusu olmamaktadır. Aşağıdaki Tablo 10, bu eksikliği gidermek üzere, yabancı sermayeli mevduat bankalarının TFV düzeyinin dönem içindeki gelişiminin bileşenlerini izlemek amaciyla oluşturulmuştur.

Tablo 10. Yabancı Sermayeli Bankalarda TFV Bileşenlerinin Gelişimi (2006 - 2012)

\begin{tabular}{|c|c|c|c|c|c|c|}
\hline Banka & Yll & $\begin{array}{c}\text { Teknik } \\
\text { Etkinlik } \\
\text { Değişimi } \\
(\mathbf{1 = 3 x 4 )}\end{array}$ & $\begin{array}{l}\text { Teknolojik } \\
\text { Değişim } \\
\text { (2) }\end{array}$ & $\begin{array}{c}\text { Pür Teknik } \\
\text { Etkinlik } \\
\text { Değişimi } \\
\text { (3) }\end{array}$ & $\begin{array}{c}\text { Ölçek } \\
\text { Etkinliği } \\
\text { Değişimi } \\
\text { (4) }\end{array}$ & $\begin{array}{c}\text { Toplam } \\
\text { Faktör } \\
\text { Verimliliği } \\
\text { Endeksi } \\
(5=1 \times 2)\end{array}$ \\
\hline \multirow{6}{*}{ Denizbank } & $2006-2007$ & 1,155 & 1,058 & 1,153 & 1,001 & 1,222 \\
\hline & $2007-2008$ & 1,000 & 1,064 & 1,000 & 1,000 & 1,064 \\
\hline & $2008-2009$ & 1,000 & 0,983 & 1,000 & 1,000 & 0,983 \\
\hline & $2009-2010$ & 1,000 & 0,981 & 1,000 & 1,000 & 0,981 \\
\hline & $2010-2011$ & 0,984 & 0,982 & 1,000 & 0,984 & 0,966 \\
\hline & $2011-2012$ & 0,952 & 1,036 & 0,960 & 0,992 & 0,987 \\
\hline \multirow{6}{*}{ Finans Bank } & $2006-2007$ & 1,000 & 1,183 & 1,000 & 1,000 & 1,183 \\
\hline & $2007-2008$ & 1,000 & 0,989 & 1,000 & 1,000 & 0,989 \\
\hline & $2008-2009$ & 1,000 & 1,064 & 1,000 & 1,000 & 1,064 \\
\hline & $2009-2010$ & 1,000 & 0,851 & 1,000 & 1,000 & 0,851 \\
\hline & $2010-2011$ & 1,000 & 0,981 & 1,000 & 1,000 & 0,981 \\
\hline & $2011-2012$ & 1,000 & 0,957 & 1,000 & 1,000 & 0,957 \\
\hline \multirow{6}{*}{ HSBC Bank } & $2006-2007$ & 1,000 & 0,979 & 1,000 & 1,000 & 0,979 \\
\hline & $2007-2008$ & 0,983 & 0,962 & 1,000 & 0,983 & 0,945 \\
\hline & $2008-2009$ & 1,018 & 1,030 & 1,000 & 1,018 & 1,048 \\
\hline & $2009-2010$ & 0,839 & 0,970 & 0,870 & 0,965 & 0,814 \\
\hline & $2010-2011$ & 1,003 & 0,974 & 0,980 & 1,023 & 0,977 \\
\hline & $2011-2012$ & 1,089 & 0,997 & 1,173 & 0,929 & 1,086 \\
\hline \multirow{6}{*}{ ING Bank } & $2006-2007$ & 1,087 & 1,170 & 1,082 & 1,005 & 1,272 \\
\hline & $2007-2008$ & 0,965 & 1,014 & 0,991 & 0,973 & 0,978 \\
\hline & $2008-2009$ & 1,036 & 1,002 & 1,009 & 1,027 & 1,039 \\
\hline & $2009-2010$ & 1,000 & 1,015 & 1,000 & 1,000 & 1,015 \\
\hline & $2010-2011$ & 1,000 & 0,986 & 1,000 & 1,000 & 0,986 \\
\hline & $2011-2012$ & 1,000 & 1,000 & 1,000 & 1,000 & 1,000 \\
\hline
\end{tabular}


Tablo 10'dan görüleceği gibi yıllar içinde TFV endeks değerinde bazı oynamalar söz konusudur. Banka bazında bu değişiklikleri değerlendirdiğimizde ilk dikkat çeken noktalardan birisi yabancı sermayeli bankalar içinde TFV düzeyi artışı açısından en başarılı yılın 2007 olduğudur. Nitekim tablodan görüldüğü gibi 2007 yılında ING Bank \%27,2, Denizbank \%22,2 ve Finans Bank \%18,3 oranında TFV artışı sağlamıştır. 2007 yılında TFV düzeyini 2006 yılına göre gerileten tek banka HSBC Bank’tır. Öte yandan HSBC Bank zaten yedi dönemlik analizimiz bütünü içinde y1llık ortalama \%2,9 oranında TFV gerilemesi ile en kötü performans gösteren üçüncü bankadır. Kaldı ki, 2007 yılı HSBC için de, 2009'dan sonra göreli olarak en iyi performansın olduğu yıldır. Bu nedenle genel olarak 2007 yılının yabancı bankalar açısından TFV düzeyini geliştirebildikleri olumlu bir yıl olduğu rahatlıkla ifade edilebilir.

Analiz kapsamında yer alan dört yabancı bankanın TFV endeksinin yedi dönemlik değerlendirmesinden, toplam olarak 24 adet TFV endeksi hesaplanmıştır. Bunların yalnızca birinde (ING Bank ve 2012 yıl1) 1 değerine ulaşılmıştır. 9 değer 1'in üstündeyken, 14 değer 1'den küçüktür. Buna göre genel olarak TFV düzeyinde gerilemenin olduğu yıl sayısı daha fazladır. Buna karşılık daha önce incelenen Tablo 9'dan görüldüğ̈̈ gibi ortalama TFV düzeyi yalnızca bu dört bankadan birinde (HSBC Bank) TFV düzeyinde anlamlı bir gerileme vardı. Dolayısıyla TFV düzeyinde gelişme oranlarının, gerileme oranlarından daha yüksek olduğu belirtilebilir.

TFV düzeyinin iki alt bileşeninden teknik etkinlik değişimi ve teknolojik değişim değerlerine bakıldığında dikkati çeken durum teknolojik değişimin daha önemli olduğudur. Nitekim her bir endeks için hesaplanan 24 değerin, teknik etkinlik değişimi bileşeninde 11'i, teknolojik değişim bileşeninde 23'ü 1'den farklı bir değer almıştır. Buna göre, 2006 - 2012 döneminde dört bankanın genel olarak teknolojik değişime bağlı bir TFV değişimi ile yaşadıkları görülmektedir. Teknolojik değişmenin üretim sınır eğrisinin yer değiştirmesini ifade ettiği dikkate alındığında, yabancı sermayeli bankaların yeniliklere bağlı bir toplam faktör verimliliği değişimi yaşadıkları ifade edilebilir.

Teknik etkinlik değişiminin alt bileşenleri açısından bir değerlendirme yapıldığında dört yabancı sermayeli banka için genel olarak ölçek etkinliği değişiminin TFV düzeyini olumsuz etkilediği, bir başka ifadeyle bankaların uygun ölçekte faaliyet gösterme konusunda sıkıntılarının olduğu dikkati çekmektedir. Dört banka için hesaplanan 24 ölçek etkinliği değişimi değerlerinin ortalaması y1llık \%0,4 oranında verimlilik gerilemesinin bu alt bileşenden kaynaklandığını göstermektedir. Buna karşılık pür teknik etkinlik değişimi için hesaplanan değerlerin ortalaması yıllık $\% 0,9$ oranında verimlilik iyileşmesinin bu alt bileşenden kaynaklandığını göstermektedir. Dolayısıyla TFV üzerinde teknik etkinlik değişiminin net etkisi olumlu olmaktadır. Ancak bu olumlu etki, yukarıda da ifade edildiği gibi, teknolojik değişimin etkisinden daha sınırlı düzeydedir.

Banka bazında değerlendirme yapıldığında Denizbank TFV değişimi açısından 2007 yılında oldukça başarılı görünmektedir. Anılan yıl TFV düzeyini \%22,2 düzeyinde geliştirebilmiş olan 
Denizbank, bu değişimi büyük ölçüde teknik etkinlik değişiminden sağlamıştır. Bir başka ifadeyle 2007 yılında Denizbank üretim sınırını yakalama (catching up) etkisini yakalamıştır. Bunun alt bileşenlerine baktığımızda da pür teknik etkinlik değişiminin etkili olduğunu görmekteyiz. Ancak sonraki yıllarda benzer bir verimlilik artışı sağlayamadığı da dikkati çekmektedir. TFV düzeyini geliştirebildiği son yıl olan 2008 yılında ise bu gelişmenin gerisinde, 2007 yılından farklı olarak teknolojik değişim yatmaktadır. İzleyen yıllarda ise Denizbank sınırı ölçüde olsa da, TFV düzeyinin gerilemesini önleyememiştir.

Finans Bank 2007 ve 2009 yıllarında TFV düzeyini sırasıla \%18,3 ve \%6,4 oranında iyileştirebilmiştir. Bu iyileşme teknolojik değişime dayalı olarak gerçekleşmiştir. Diğer yıllarda TFV düzeyinde gerilemeler söz konusudur ve özellikle 2010 yılındaki \%14,9 oranındaki gerileme dikkat çekicidir. Finans Bank'ın TFV düzeyi açısından belirleyici olan tek alt bileşen teknolojik değişim olmuştur. Diğer alt bileşenlerin TFV düzeyi açısından etkisi nötr kalmıştır.

HSBC Bank özelinde bir değerlendirme yapıldığında yukarıdaki Tablo 10'dan görüldüğü gibi TFV açısından en iyi performans 2012 yılında, en kötü performans 2010 yılında elde edilmiştir. 2012 yılındaki \%8,6 düzeyinde TFV iyileşmesinin gerisinde büyük ölçüde \%17,3 oranında gerçekleşen pür teknik etkinlik değişimi belirleyicidir. Ölçek etkinliği değişimindeki \%7,1 oranındaki negatif etki, pür teknik etkinlik değişiminin katkısını törpülese de, anılan yıl teknik etkinlik değişimi \%8,9 düzeyinde gerçekleşebilmiştir. Diğer yıllarda ise genellikle teknolojik değişimdeki negatif etkinin baskın olduğu dikkati çekmektedir.

ING Bank, analiz kapsamında değerlendirilen dört yabancı sermayeli banka içinde TFV düzeyini en fazla geliştirebilen bankadır. Diğer bankalarda ikişer yıl TFV düzeyi iyileşmesi söz konusuyken ING Bank 2007, 2009 ve 2010 yıllarında TFV artışı sağlayabilmiş; 2008 ve 2011 y1llarında, sırasıyla \%2,2 ve \%1,4 gibi düşük oranlarda TFV gerilemesi yaşamıştır. 2012 yılında ise TFV düzeyi 2011 yılıyla aynı seviyede kalmıştır. ING Bank TFV düzeyindeki bu gelişmenin hangi alt bileşenlerden kaynaklandığına bakıldığında, öne çıkan unsurun teknolojik değişim olduğu görülmektedir.

Sonuç olarak yabancı bankaların TFV düzeyindeki değişmelerin alt bileşenleri açısından genellikle pür teknik etkinlik değişiminin ve ölçek etkinliği değişiminin sınırlı etkiye sahip olduğunu, hem olumlu hem olumsuz değişimde teknolojik değişmenin öne çıktı̆̆ söylenebilir.

\section{SONUÇ}

Küreselleşme ve geniş bir alandaki uygulamalarıyla liberalizasyon süreci sonrasında her alanda rekabet daha da yoğunlaşmış, rekabete açık alanlar oldukça genişlemiş̧tir. Rekabetin gerek ulusal gerekse küresel düzeyde yoğunlaşması verimlilik ve etkinlik kavramlarının daha da önem kazanmasına neden olmuştur. Her bir sektöre farklı düzeylerde de olsa mutlaka yansıyan bu 
gelişmelerden bankacılık sektörü de etkilenmiştir. Birçok ülkede bu etkilenme hem sektörün yabancılara açılması hem de rekabetin yoğunlaşması boyutlarından gerçekleşmiştir.

1980 yılında dış ticaretini, 1989 yılında da sermaye hareketlerini liberalize eden Türkiye'de bankacılık sektöründe çok önemli gelişmeler yaşanmış, bu gelişmelerin önemli göstergelerinden biri de yabancı bankaların Türkiye'ye girişi olmuştur. Kimisi satınalma, kimisi ortaklık ve kimisi de menşe ülkedeki adıyla doğrudan olmak üzere farklı yöntemlerle ülkeye giren yabancı bankaların gerek sektör genelindeki gerekse tekil bankalar düzeyinde gerçekleştirdikleri verimlilik artışlarının analizi yabancı bankaların verimlilik, etkinlik ve dolayısıyla da rekabet üzerine etkilerini değerlendirmeye imkan vermektedir.

$\mathrm{Bu}$ değerlendirmeleri yapabilmek amacıyla bu çalışmada sermaye mülkiyetine göre gruplandırmada küçük / büyük ölçekli banka ayrımına gidilmeden grupta yer alan tüm bankaların girdi ve çıktıları kullanılarak Malmquist Toplam Faktör Verimliliği Endeksi hesaplanmıştır. Hesaplama sonuçlarına göre analiz edilen 2006-2012 dönem ortalaması olarak en yüksek endeks değerine yabancı, en düşük endeks değerine ise kamu bankaları sahip olmuştur. Bu durum toplam faktör verimliliği göstergesi boyutuyla inceleme döneminde yabancı bankaların daha etkin olduğunu ortaya koymuştur. Çalışmada ayrıca yabancı bankaların daha çok küresel ekonomik gelişmelerden, yerli bankaların ise Merkez Bankasının politikaları ile iç ekonomik konjonktürden daha fazla etkilendiği anlaşılmıştır.

Bankalar bazında yapılan analizlerde ise TFV endeksinde gerek yıldan yıla gerekse 2006-2012 dönem ortalaması itibariyle ortaya çıkan değişimlerin oldukça farklılık gösterdiği; TFV'nin kamu sermayeli bankalarda azalış, özel sermayeli bankalar az da olsa artış, yabancı sermayeli bankaların daha yüksek bir artış yaşandığı anlaşılmıştır. TFV açısından, yabancı sermayeli bankalarda en iyi performansı ING Bank, en kötü performansı HSBC Bank; özel sermayeli bankalarda en iyi performansı Şekerbank, en kötü performansı Türkiye İş Bankası; kamu sermayeli bankalarda en iyi performansı Türkiye Vakıflar Bankası, en kötü performansı Türkiye Cumhuriyeti Ziraat Bankası göstermiştir.

Çalışmada ayrıca Toplam Faktör Verimliliğini belirleyen iki alt bileşen yani teknolojik etkinlik ve teknolojik değişmeye ilişkin analizler de gerçekleştirilmiştir. Buna göre analiz kapsamındaki tüm bankalar açısından, TFV üzerinde teknolojik değişimin genellikle olumsuz, teknik etkinlik değişiminin ise olumlu etkide bulunduğu anlaşılmıştır. Yabancı sermayeli bankalar açısından, analiz kapsamındaki bankalar bütünün aksine, her iki alt bileşenin TFV üzerinde etkisi olumlu iken, teknolojik değişimin daha yüksek, teknik etkinlik değişiminin daha sınırlı olumlu etkisinin olduğu tespit edilmiştir.

Sonuç olarak denilebilir ki, sektör aktifleri içindeki payı yüzde 1'in üzerinde olan bankaların TFV değişimlerini analiz ettiğimiz çalışmamız, yabancı sermayeli bankaların, diğer bankalara göre daha yüksek verimlilik düzeyinde faaliyetlerini sürdürdüğünü ortaya koymuştur. 2012 y1lı itibariyle 
sektör toplam aktifleri içinde yabancı sermayeli bankaların payı yalnızca yüzde 11,4 düzeyindedir. Buradan hareketle, yabancı sermayeli bankaların TFV artışı sağlamış olmalarının sektör toplamındaki etkisinin sınırlı kalacağını belirtmek gerekir. Öte yandan, yabancı sermayeli bankaların göstermiş oldukları teknolojik değişim kaynaklı TFV artışının sektörün tümüne yaygınlaşabilmesi ölçüsünde, Türkiye bankacılık sektörünün daha verimli çalışacağı açıktır. Özellikle küresel finansal piyasalardaki çalkantıların etkisine giderek daha fazla maruz kalacak, gelişmekte olan ülke statüsündeki Türkiye'nin, bu olumsuz etkilerle başa çıkabilmesi için bankacılık sektörünün önemi artacaktır. Bu öneme paralel olarak, Türkiye bankacılık sektöründe yer alan her bir bankanın verimlilik artırıcı uygulamalara yönelmesi, ekonomi yönetiminin ve sektör düzenleme otoritelerinin bu yönelimi teşvik edecek biçimde tavır alması, ekonominin sadece finansal değil reel boyutunun ihtiyaçları açısından da bir zorunluluktur.

\section{KAYNAKÇA}

Akgüç, Ö. (2007) “Türkiye’de Yabancı Bankalar” Muhasebe ve Finansman Dergisi, 36.

Aracıoğlu, B. ve Demirhan, D. (2011) "Kriz Öncesi ve Kriz Sonrası Dönemler İtibariyle Finansal Hizmetler Sektöründe Faaliyet Gösteren İşletmelerin Etkinliklerinin Veri Zarflama Analizi İle Değerlendirilmesi”, Dayanışma, İzmir Serbest Muhasebeci ve Mali Müşavirler Odası Dergisi, 111: $23-35$.

Aydın, Ü. (2010) "Finans Endüstrisinde Karşılaştırmalı Organizasyonel Etkinlik: Türkiye Örneği”, Doktora Tezi, Dokuz Eylül Üniversitesi, Sosyal Bilimler Enstitüsü, İktisat Programı, İzmir.

Bayraktar, N. ve Wang, Y. (2004) "Foreign Bank Entry Performance of Domestic Bank and Sequence Financial Liberalization" Second Draft, 18 August.

BDDK (2005) "Bankacılık Sektörüne Yabancı Girişi: Küresel Gelişmeler ve Türkiye”, ARD Çalışma Raporlar1 No: 2005/6, http://www.bddk.org.tr/websitesi/turkce/Raporlar/Calisma Raporlari/13012005-6.pdf, (01.02.2013).

BDDK (2008) “Bankacılıkta Yapısal Gelişmeler”, BDDK - Strateji Geliştirme Daire Başkanlı̆̆ı, Sayı: 3, Aralık, Ankara.

BDDK (2009) “Bankacılıkta Yapısal Gelişmeler”, BDDK - Strateji Geliştirme Daire Başkanlığı, Sayı: 4, Aralık, Ankara.

BDDK (2010) “Bankacılıkta Yapısal Gelişmeler”, BDDK - Strateji Geliştirme Daire Başkanlığı, Sayı: 5, Aralık, Ankara.

BDDK (2011) “Bankacılıkta Yapısal Gelişmeler”, BDDK - Strateji Geliştirme Daire Başkanlığı, Sayı: 6, Aralık, Ankara. 
Behdioğlu, S. ve Özcan, G. (2009) "Veri Zarflama Analizi ve Bankacılık Sektöründe Bir Uygulama", Süleyman Demirel Üniversitesi İktisadi ve İdari Bilimler Fakültesi Dergisi, 14 (3): 301 - 326.

Berger, A. N. ve D. B. Humphrey (1997) "Efficiency of Financial Institutions: International Survey and Directions for Future Research", European Journal of Operatinal Research, 98: 175 - 212.

Budak, H. (2011) "Veri Zarflama Analizi ve Türk Bankacılık Sektöründe Uygulaması", Marmara Üniversitesi Fen Bilimleri Dergisi, 23 (3): 95 - 110.

Cardenas, J. ve Graf, J. P. ve O’Dogherty, P. (2003) "Foerign Banks Entry in Emerging Market Economies:A Host Country Perspective”, Banco de Mexico Paper, www.bis.org, (06.08.2007).

Cingi, S. ve Tarım, Ş. A (2000) “Türk Banka Sisteminde Performans Ölçümü: DEA - Malmquist TFP Endeksi Uygulaması”, Türkiye Bankalar Birliği Araştırma Tebliğleri, Sayı: 2000 - 01.

Claessens, S. ve Kun, J. (2002) "LeeForeing Banks in Low- Income Countries: recent Developmnets and Impacts" The World Bank, www1.fee.uva.nl, (14.09.2007).

Claessens, S.ve Demirgüç-Kunt, A. ve Huizinga, H. (1998) "How Does Foreign Entry Affect The Domestic Banking Market,”, www.worldbank.org, (01.08.2007)

Clarke, G. R. G.ve Cull, R. ve Peria, M. S. M. (2002) "Does Foreign Bank Penetration Reduce Access To Credit İn Developing Countries? Evidence From Asking Borrowers, www.worldbank.org, (01.08.2007).

Coşkun, N. ve diğerleri, (2012) Türkiye'de Bankacılık Sektörü Piyasa Yapısı, Firma Davranışlanı ve Rekabet Analizi, Türkiye Bankalar Birliği, İstanbul.

Çipil, F. (2011) "Karayolu Ulaştırma Sisteminin Toplam Faktör Verimliliği ve Avrupa Birliği Konum Analizi”, Yayınlanmamış Doktora Tezi, Gazi Üniversitesi Fen Bilimleri Enstitüsü, Ankara.

Demir, Y. ve Gençtürk, M. (2006) “iMKB'de İşlem Gören Yerli ve Yabancı Bankaların Göreli Etkinliklerinin Veri Zarflama Analizi İle Ölçümü”, DEÜï̇BF Dergisi, 21 (2): 49 - 74.

Demirgüç- Kunt, A. ve Detragiache, E. (1998) "Financial Liberalization and Financial Fragility”, IMF Working Paper, http://www.imf.org/external/pubs/ft/wp/wp9883.pdf, (05.06.2010).

Denizer, C. (1999) "Foreing Entry in Turkey's Banking Sector:1980-1997, The World Bank", (14.09.2007).

Denizer, C. Dinç, M. (2000) "Measuring Banking Efficiency in Pre- And Post- Liberaliation Environment: Evidence from the Turkish Banking System” World Bank, (16.08.2007).

Ekren, N. ve Emiral, F. (2002) "Türk Bankac1lık Sisteminde Etkinlik Analizi (Veri Zarflama Analizi Uygulamas1)", Active Bankacılık ve Finans Dergisi, 4(24): 6 - 27. 
Floro, M. ve Dymski, G. (2000) "Finacial Crisis, Gender and, Power: An Analyical Framework", World Development, 28 (7).

Haas, R.T.A. de ve Lelyveld, I.P.P van, (2002) “ Foreign Bank Penetration and Private Sector Credit in Central and Eastren Europe", DNB Staff Reports. No. 91/2002,http://www.cepr.org/meets/wkcn/5/580/papers/lelyveld.pdf, (25.02.2013).

Haselmann, R. ve Vig, V. (2007) “The Differantial İmpact of Financial Liberalization”,February, http://www.bundesbank.de/Redaktion/EN/Downloads/Bundesbank/Research_Centre/conference s/2007/2007_06_21_eltville_01_haselmann_vig_paper.pdf?_blob=publicationFile, (01.03.2010)

Hellman, T. F. ve. Murdock, K. C. ve Stiglitz, J. E. (2000) "Liberalization, Moral Hazard in Banking and Prudential Regulation: Are Capital Requirements Enough? “, American Economic Review , Vol 90, No:1. www. strategy.sauder.ubc.ca, (02.08.2007)

Işık, İ. ve Uysal, D. (2006) “The Sources of Productivity Growth in Turkish Banks by Ownership: The Initial Responses of Public, Private, and Foreign Banks to Liberalization, Turkish Studies", Vol 7, No 3, http://www.tandfonline.com/doi/pdf/10.1080/14683840600891059, (04.02.2013)

Kaminsky, G. L. Ve Schmukler, S.L. (2002) "Short- Run Pain, Long- Run Gian: The Effects Of Financial Liberalization", www.worldbank.org, (03.08.2007).

Köksal, C. D. (2001) “Veri Zarflama Analizi İle Bankacılıkta Göreceli Verimlilik Ölçümü”, Doktora Tezi, Süleyman Demirel Üniversitesi Sosyal Bilimler Enstitüsü, Isparta.

Lensink, R. ve Hermes, N. (2004) "The short-term effects of foreign bank entry on domestic bank behaviour: Does economic development matter? “, Journal of Banking and Finance, Volume 28, Issue 3, pp. 553-568, www.bdk.rug.nl, (03.07.2007).

Okuda, H.ve Rungsomboon, S.(2004) "The Effects of Foreign Bank Entry on The Tai Banking Market Empirical Analysis From 1990 To 2002”, CEI Working Paper Series, No: 2004-20.

Öncü, S. ve Aktaş, R. (2007); "Yeniden Yapılandırma Döneminde Türk Bankacılık Sektöründe Verimlilik Değişimi”, Yönetim ve Ekonomi, Celal Bayar Üniversitesi İktisadi ve İdari Bilimler Fakültesi Dergisi, 14(1): 247 - 266.

Pasadilla, G ve Milo, M. (2005) "Effect of Liberalization on Banking Competition",Philipinne Institute for Development Studies, Discussion Paper Series No:2005-3, www3.pids.gov.ph, (08.08.2007).

Ribon, S.ve Yosha, O. (2001) "Financial Liberalization and Competition in Banking: An Emprical Investigation", The Bank of Israel Research Deparment, Discusion Paper No:99.05, www.bankisrael.gov.il, (08.08.2007). 
Seyrek, İ. H. ve Ata, H. A. (2010) "Veri Zarflama Analizi ve Veri Madenciliği ile Mevduat Bankalarında Etkinlik Ölçümü”, BDDK Bankacılık ve Finansal Piyasalar Dergisi, 4(2):67 - 84.

Sturm, J. E. ve Williams, B. (2002) "Deregulation, Entry of Foreign Banks and Bank Efficiency in Australia", CESIFO Working Paper, N: 816, Erişim: 26.08.2013, http://www.cesifogroup.de/portal/page/portal/lang-en/DocBase_Content/WP/WP-CESifo_Working_Papers/wpcesifo-2002/wp-cesifo-2002-12/cesifo_wp816.pdf

Şen, S. A. (2006) "Bankacılık Sektörü ve Devlet Müdahaleleri: Politik Devresel Dalgalanmalar Çerçevesinde Türk Bankacılık Sektörü Etkinlik Analizi”, Sosyoekonomi Dergisi, 2(4): 11 - 30.

Tarım, A. (2001) “Veri Zarflama Analizi - Matematiksel Programlama Tabanlı Göreli Etkinlik Ölçüm Yaklaşımı”, Sayıştay Başkanlığı Yayınları No: 15, Ankara.

Türker, K., Doğan, Y. ve Doğan, E. (2005) "Desenflasyon Sürecinde Türk Bankacılık Sektöründe Etkinliğin Gelişimi”, BDDK ARD Çalışma Raporları 2005/10, Kasım, Ankara

Türkiye Bankalar Birliği (1998) "40.Yılında Türkiye Bankalar Birliği ve Türk Bankacılık Sistemi ‘1958-1997’, TBB, Yayın No: 207, İstanbul.

Türkiye Bankalar Birliği, Bankalarımız Kitabı çeşitli sayılar, www.tbb.org.tr.

Yaşa, A. (2008) "Bankac1lık Sektöründe Etkinlik ve Veri Zarflama Analizi Yöntemi İle Ölçülmesi”, Yayınlanmamış YL Tezi, Ankara Üniversitesi Sosyal Bilimler Enstitüsü, Ankara. 